\title{
Seasonal Effects of Water Quality on Infant and Child Health in India
}

\author{
Elizabeth Brainerd \\ Nidhiya Menon
}

Version: December 2, 2011

\begin{abstract}
This paper examines the impact of fertilizer agrichemicals in water on infant and child health using data on water quality combined with data on the health outcomes of infants and children from the 1992-93, 1998-99, and 2005-06 Demographic and Health Surveys of India. Because fertilizers are applied at specific times in the growing season, the concentrations of agrichemicals in water vary seasonally and by agricultural region as some Indian states plant predominantly summer crops while others plant winter crops. Our identification strategy exploits the differing timing of the planting seasons across regions and differing seasonal prenatal exposure to agrichemicals to identify the impact of agrichemical contamination on various measures of child health. The results indicate that children exposed to higher concentrations of agrichemicals during their first trimester experience worse health outcomes on a variety of measures (infant mortality, neo-natal mortality, height-for-age z scores and weight-for-age z-scores). Disaggregated runs reveal that effects are largest amongst the most vulnerable groups - children of uneducated poor women living in rural India.
\end{abstract}

J.E.L. Classification Codes: O12, I15, Q53, Q56

Key words: Fertilizer Agrichemicals, Water Pollutants, Child Health, Infant Mortality, India

Thanks to Andrew Foster, Dilip Mookherjee, and John Strauss for comments on research design. Thanks to Linda Bui and other lunch series seminar participants at Brandeis for comments on an earlier version. We are grateful to Rema Hanna and Michael Greenstone for sharing their subset of Central Pollution Control Board's (CPCB) data on water pollution measures. We extend our gratitude to many people at CPCB especially J.S.

Kamyotra, D.D. Basu, and Rajendra Bhardwaj, for facilitating access to and for answering numerous questions on the water data. Thanks also to Kelly Hodgson at UNEP GEMS/Water Program for help with the India data. Menon thanks the International Growth Center's India Central Program for financial support. Yubing Cui, Carol Hughes-Hallett Ramos, Tarini Nalwa, Udit Patwardhan, and Ari Pipe-Mazo provided excellent research assistance. The usual disclaimer applies. Address for correspondence: Elizabeth Brainerd, Susan and Barton Winokur Professor in Economics and Women's and Gender Studies, Department of Economics, MS 021, Brandeis University, Waltham, MA 02454. Tel.781.736.4816. Email: ebrainer@brandeis.edu. Nidhiya Menon, Associate Professor of Economics, Department of Economics, MS 021, Brandeis University, Waltham, MA 02454. Tel.781.736.2230. Email: nmenon@brandeis.edu. 


\section{Introduction}

The Green Revolution in India transformed the country from one heavily reliant on imported grains and prone to famine to a country largely able to feed itself and successful in achieving its goal of food security. Yields of the country's main crops, wheat and rice, increased dramatically and farmers prospered from the use of Green Revolution technologies including high-yield variety seeds, irrigation, pesticides and nitrogenous fertilizer. The growth in agricultural production improved the well-being of millions of Indians by reducing the incidence of hunger and raising the living standard of the rural poor, but it also exacted a toll on the country's environment. In particular, the heavy use of fertilizers to increase yields led to high levels of toxicity and contamination of surface and ground water in India.

This paper examines the impact of fertilizer agrichemicals in water on infant and child health in India. We study agro-contaminants in water as it is considered to be a reliable measure of human exposure, and use data on water quality from monitoring stations run by India's Central Pollution Control Board (CPCB) combined with data on the health outcomes of infants and children from the 1992-93, 1998-99, and 2005-06 Demographic and Health Surveys (DHS) of India. We focus on fertilizers because they have relatively clear application times unlike pesticides which may be used (based on need) throughout the crop cycle. ${ }^{1}$ Because fertilizers are applied early in the growing season and residues may subsequently seep into water through soil run-off, the concentrations of agrichemicals in water vary seasonally; water contamination also varies regionally in India because regions in northern India plant predominantly winter crops while southern Indian regions plant mainly summer crops. Our identification strategy exploits the increase in fertilizer use over time in India, the differing timing of the planting seasons across India's states, and the differing seasonal prenatal exposure of infants and

\footnotetext{
${ }^{1}$ Furthermore, unlike fertilizer, pesticide use in India has remained relatively stable across the years we analyze. We should note that our measure of fertilizer includes most of the agrichemicals that compose pesticides as well. Hence our results indirectly capture pesticide effects that coincide with seasonal fertilizer utilization.
} 
children to identify the impact of agrichemical contaminants in water on various measures of child health.

Our analysis of the effects of agrichemicals provides several noteworthy results. We find that the presence of fertilizer chemicals in water in the month of conception significantly increases the likelihood of infant mortality, particularly neo-natal mortality. Consistent with the public health literature that male children are more sensitive to environmental insults, we find (imprecisely measured) evidence that the presence of fertilizer agrichemicals in the month of conception reduces the likelihood that the gender of the child is male. The presence of toxins in water in the first month is also associated with reduced birth weight (measured with error), and significantly reduced height-for-age and weightfor-age $\mathrm{z}$ scores for children below five years of age. Disaggregated runs reveal that the effects are most evident for vulnerable populations - children of uneducated poor women living in rural India.

Evaluating the link between water agrichemical contamination and child health in India is important for several reasons. First, in rural India, women form a significant part of the agricultural labor force and are often at the forefront of farming activities. This suggests that they are directly exposed to chemical applications that are made to the soil to improve productivity; their children are exposed both in utero and after birth to these toxins and at these young ages are highly vulnerable to environmental contaminants. This exposure may contribute to the relatively poor indicators of child health in India: Indian children have one of the highest rates of stunting and wasting among all developing countries; these rates are higher than predicted given the level of per capita income and infant mortality rates in the country. ${ }^{2}$ Second, since water is motile, high levels of chemical contaminants in water have the potential to affect individuals outside of farming communities. Thus, elevation in pollutant levels in water that occur in crop-sowing months may negatively impact women

\footnotetext{
${ }^{2}$ See Deaton and Drèze (2009) for a discussion of the relatively poor anthropometric indicators for Indian children.
} 
and children outside of rural agriculture. Third, evidence from biomedical studies indicates that seasonal exposure to water toxins can affect health outcomes not only in the current population but also in subsequent generations. For example, illnesses such as coronary heart disease which has been shown to be more likely in adults who as babies were of low-birth weight are inheritable, and may be bequeathed to subsequent generations. Such transmission occurs even without any additional exposure to the chemical contaminants that caused the health problems in the preceding generation. The impact of water pollution on all of these dimensions of health in developing countries has largely been neglected in the economics literature, as we discuss below.

The paper is structured as follows. The next section provides a brief overview of the economics and biomedical literature on pollution and child health outcomes in developed and developing countries. The section that follows describes the implementation and impact of the Green Revolution in India, the features of the planting and growing seasons of rice and wheat which we exploit in the paper, and water quality and its regulation in India. We then describe our methodology and data and present our main results. Alternative specifications and robustness checks are presented thereafter, and the paper concludes with a discussion of implications for policy.

\section{Previous Literature}

This research fits into several strands of literature in economics. An active area of current research examines the impact of air pollution and other contaminants on infant mortality and child health in developed countries. Many of these studies focus on the United States and use the discontinuity in air pollution created by plausibly exogenous events such as the Clean Air Act, economic recession which reduces industrial activity and emissions, and the introduction of electronic tolls on highways which reduced idling time and car exhaust. These studies document a statistically significant and quantitatively large effect of reduced air pollution on infant and child health (Chay and Greenstone 
2003, Currie and Walker 2011, Sanders and Stoecker 2011). ${ }^{3}$ Other papers analyzing the impact of negative health shocks on infants in utero, such as exposure to the 1918 influenza epidemic and radiation fallout from the 1986 Chernobyl disaster (Almond 2006; Almond, Edlund and Palme 2009) further confirm the vulnerability of infants to prenatal exposure to contaminants and underscore the long-lasting effects such exposure can have, extending well into adulthood.

Relatively few studies have examined the impact of pollution on health in developing countries, and these have primarily considered the effects of indoor air pollution on child and adult health (see, for example, Pitt et al. 2006, and Duflo et al. 2007). The work most closely related to ours is Greenstone and Hanna (2011), which assesses the impact of air and water quality regulations on infant mortality across Indian cities for the years 1986-2007. Using air and water pollution data from India's CPCB combined with data on air and water quality regulations, they find that air quality regulations significantly reduced air pollution, which in turn led to a modest (statistically insignificant) reduction in infant mortality; however, the water pollution regulations have been ineffective at reducing measures of surface water pollution. As these authors discuss, the implementation of the water quality policies appears to be weak and underfunded in India. Moreover, Greenstone and Hanna (2011) limit their evaluation to the effect of three consistently measured water pollutants - faecal coliform, biochemical oxygen demand, and dissolved oxygen. Their study does not consider the implications of fertilizer agrichemicals in water on infant and child health.

A second strand of literature examines the contributions of public health measures (e.g., reduced exposure to lead; enhanced water quality) to improvements in population health. Studies in this area include Cutler and Miller (2005) which demonstrates that access to clean water through filtration and chlorination was associated with large reductions in infant and child mortality between 1900 and 1936 in

\footnotetext{
${ }^{3}$ See Almond and Currie (2011) for a comprehensive review of this literature.
} 
the United States. Similarly, the privatization of local water companies in Argentina in the 1990s was associated with increased access to clean water and a significant reduction in child mortality (Galiani, Gertler and Schargrodsky 2005).

In contrast to the limited economics research on the detrimental health impacts of poor water quality in developing countries, biomedical studies in the developed world document the relationship between chemicals in water and risks to adult and infant health relatively well. Winchester et al. (2008) shows that in the United States (US), there is a significant correlation between seasons of high agrichemical content in water and total birth defects. Garry et al. (2002) finds that in Minnesota, pesticide applicators had high rates of specific birth defects and that the risk was most pronounced for infants conceived in the crop-sowing spring months of April to June. Public health studies that focus on developing countries include Heeren et al. (2003) and Restropo et al. (1990). Heeren et al. (2003) reports a positive correlation between agricultural chemical exposure and birth defects in South Africa, whereas Restropo et al. (1990) analyzes the prevalence of abortions, prematurity, and stillbirths among female workers and wives of male workers employed in the floriculture industry of Colombia where pesticide use is widespread. Given resource constraints and high contamination levels, it is likely that the damaging health impacts of agrichemicals are more pronounced and widespread in other poor countries such as India. ${ }^{4}$ An evaluation of this topic using the lens of economics is thus highly relevant.

\section{The Green Revolution, Agriculture, and Water Quality in India}

At independence in 1947, agriculture in India was characterized by labor-intensive subsistence farming methods that resulted in low yields and continued vulnerability to inadequate food supplies. The country had suffered a devastating famine - the Bengal famine of 1943 - in which an estimated two

\footnotetext{
${ }^{4}$ Indeed we find aggregate state/year-level evidence that the incidence of miscarriages, stillbirths, and abortions is positively associated with levels of nitrogen and phosphate in water (nitrogen is measured imprecisely), and the incidence of having a prematurely born child is also positively associated with these fertilizer agro-components. These results are not reported in the paper but are available on request.
} 
to four million people died and which has been discussed before in the economics literature (Sen 1977). Indian leaders considered food security to be of paramount importance after independence and implemented programs to achieve this goal, including promotion of modern farming techniques broadly referred to as the "Green Revolution." These techniques were developed by the Nobel-prize winning scientist Norman Borlaug and were implemented across many developing countries including India beginning in the mid-1960s. Green Revolution methods primarily entailed (i) increased area under farming; (ii) increased use of irrigation; (iii) double-cropping, that is planting two crops rather than one annually; (iv) use of high-yield variety (HYV) seeds; and (v) significantly increased use of inorganic fertilizers and pesticides.

HYV seeds can increase crop yields by two to four times those of indigenous seeds, but they require more fertilizer and water than do indigenous seeds. Besides high yields, these seeds also have a shorter growing cycle than traditional seeds and thus in some areas crops may be planted twice (double cropped). The main HYV seeds used in India were wheat (K68) and rice (IR8, or "Miracle Rice"). The diffusion of HYV seeds proceeded rapidly in India, particularly for wheat; for example the share of acreage under wheat sown with HYV seeds increased from 4.1 percent in the first year of the program (1966-67) to 30.0 percent only two years later. Over the same period, consumption of nitrogenous fertilizer increased from 658,700 metric tons to $1,196,700$ metric tons, and consumption of phosphatic and potassic fertilizer increased by similar proportions (Chakravarti 1973).

As illustrated in Figure 1, production of the country's main crops, wheat and rice, increased dramatically from 1960 to 1990. India became a net exporter of rice and wheat in 1978 (Chand 2001) and famine has not appeared again in the country since independence. At the same time, consumption of synthetic nitrogen-based fertilizers such as Urea and Nitrogen-Phosphate-Potassium (NPK) fertilizers 
rose almost nine-fold in India from the early 1960s to 2003-2004. ${ }^{5}$ Figure 2 illustrates the rapid increase in use of NPK fertilizers per hectare under cultivation between 1980 and 2008. These fertilizers are heavily subsidized by the Government of India and recent research suggests that the large subsidies are directly responsible for the overuse of inorganic nitrogen based fertilizers in many regions of India. ${ }^{6}$

The liberal use of agrochemicals has worked in tandem with rapid industrial growth in recent times to lead to high levels of water pollution in India. Water quality is monitored by India's CPCB which was established in 1974 as part of the Water Act of 1974. This legislation represented India's first effort to reduce water pollution and focused primarily on reducing industrial water pollution and extending sewage treatment facilities rather than reducing the prevalence of agrochemicals. As discussed in Greenstone and Hanna (2011), the water quality regulations to date have had a negligible impact mainly because of inconsistent implementation.

Although cross-country comparisons of water quality are difficult given differing regulations and circumstances, it appears that water pollution concentrations in India are higher than in other countries such as China and the United States (Greenstone and Hanna 2011). Focusing specifically on nitrogen levels, the primary composite of fertilizers such as NPK, Figure 3 shows that the average nitrate plus nitrate concentration in Indian water bodies is significantly higher than in the U.S. and China over a comparable time period. India's dominance in nitrogen consumption is evident even in relation to Pakistan, a neighboring country that shares many agricultural and socio-economic practices.

Moreover, the concentration of agrochemicals is likely to be higher in the months in which crops are sown. In the Netherlands, atrazine concentration peaks in June, the month when the herbicide of

${ }^{5}$ Tewatia, R.K., and T.K. Chanda (2005). "Fertilizer Use by Crop," in Fertilizer Use by Crop in India. Rome: Food and Agriculture Organization of the United Nations. Chapter 4.

${ }^{6}$ Chattopadhay, G.N., B.C. Roy, and R. Tirado (2009). Subsidising Food Crisis. Bangalore: Greenpeace India. See Bardhan and Mookherjee (2011) for an analysis of one of the subsidized farm input programs implemented in West Bengal from 1982-1995, which included provision of subsidized HYV seeds, pesticides, and fertilizers. 
which it is a component is widely applied for weed control purposes (Carr and Neary 2008). In the United States, Winchester et al. (2009) demonstrate that nitrate concentration in surface water is at its peak level in the spring months of April to June when crops are sown. The same pattern is evident for nitrogen in our water quality data for India. This is seen in Figure 4 which uses monthly data on levels of nitrogen concentration in water by type of agricultural region. The bulk of wheat production in India occurs in the northern states of Uttar Pradesh, Punjab, Haryana and Gujarat. Wheat is a rabi (winter) crop, sown beginning in November through to April, and harvested in late spring onwards. As illustrated in Figure 4, nitrogen concentrations peak in January and February in the wheat-producing states but not in the non-wheat-producing states, as would be expected. The bulk of rice production in India occurs in the southern states of Andhra Pradesh and Tamil Nadu and in the eastern states of West Bengal and Assam; rice is a kharif (summer) crop and is mainly sown in June-August and reaped in autumn. $^{7}$ It is these differences in the soil endowments across the country making some states more suitable for rice production and other states for wheat production, and the differences in the timing of crop cycles for these two main crops which will allow us to identify the impact of water agro-toxins on infant and child health.

In the following section, we describe the econometric framework which is used to evaluate the causal association between fertilizer agro-contaminants and child health in India.

\section{Identification Methodology}

The main question of interest in this research is whether live births resulting from conceptions during months of the year when fertilizer agrichemicals in water are at their highest levels (the early cropping season in wheat and rice producing states) face greater risk of negative health outcomes such

\footnotetext{
${ }^{7}$ The sowing season for rice is less clear-cut as compared to wheat. There could be several rice harvests in a year, particularly in southern India where soil and climate are more amenable. We focus on the kharif crop for rice as this is the larger harvest.
} 
as infant mortality, low birth-weight, and low levels of attainment on height-for-age and weight-for-age $\mathrm{z}$ scores as of age five. In its simplest form, this may be answered by estimating the following empirical specification:

$$
\begin{aligned}
H_{i j t}= & \beta_{0}+\beta_{1} F_{j t m_{c}}+\beta_{2} P_{j t m_{c}}+\beta_{3} X_{i j t}^{c}+\beta_{4} X_{i j t}^{w}+\beta_{5} X_{i j t}^{h}+\beta_{6} X_{i j t}^{H H}+\beta_{7} X_{j t} \\
& +\beta_{8} M_{c}+\beta_{9} T_{c}+\beta_{10} S_{j}+\beta_{11}\left(T_{c} x S_{j}\right)+\varepsilon_{i j t}
\end{aligned}
$$

where $H_{i j t}$ denotes a health outcome for child $i$ in state $j$ in year $t, F_{j t m_{c}}$ denotes the average of a dummy that measures presence of fertilizer agrichemicals in water in the state and year in $m_{c}$, the month of conception, and $P_{j t m_{c}}$ measures the presence of other water pollutants that originate from industrial activity and human presence in the state and year in $m_{c} . X_{i j t}^{c}$ are child-specific indicators (order of birth, gender, whether nursed after birth, whether delivered by caesarian-section), $X_{i j t}^{w}$ are woman (mother)-specific indicators (measures of maternal risk factors such as tobacco use and work characteristics and mother's demographic characteristics including age, education, and general health), $X_{i j t}^{h}$ are husband (father)-specific indicators (age, education, and type of work), $X_{i j t}^{H H}$ are householdspecific indicators (rural/urban indicator, age and gender of household head, household religion and caste, indicator for access to electricity and ownership of assets such as refrigerators and televisions, and data on sources of drinking water), and $X_{j t}$ are time-varying state-specific indicators (per capita net state domestic product, territorial location in India). In order to control for month and year-specific time trends and regional level heterogeneity, equation (1) includes month of conception dummies $\left(M_{c}\right)$, year of conception dummies $\left(T_{c}\right)$, region dummies $\left(S_{j}\right)$, and interactions of year of conception and region dummies. $\varepsilon_{i j t}$ is the standard idiosyncratic error term. The coefficient of interest is $\beta_{1}$ : the impact of fertilizer agrichemicals in the month of conception on child health outcomes.

We use state-year-month information on the presence of agrichemicals in water to measure in 
utero exposure to fertilizer toxins $\left(F_{j t m_{c}}\right)$. For a variety of reasons it is likely that this variable is measured with error. First, there could be both measurement and entry errors in the early days of water monitoring when technology was relatively primitive (1979-1987). Second, the number of monitoring stations has increased significantly over time (188 in 1979-1987 to 870 as of 2005). Thus early measures of water quality are less likely to accurately portray ground realities at an all-India level. Third, hard copies of annual water quality statistics handbooks reveal that monitoring stations sometimes have absent entries for inexplicable reasons. Finally, lacking information on village or district of residence of women and their children in the DHS data, we match demographic data to the water data on the basis of state of residence. The use of state-level information is a proxy for the level of toxins women and children are exposed to in their environment; the use of this proxy may result in additional errors in measurement.

For these reasons, we use instrumental variables to correct for measurement error in order to isolate the exogenous component of agrichemicals and obtain an unbiased estimate of $\beta_{1}$ in equation (1). The identifying instruments that we use are interactions of crop state (whether state is a major rice producer; whether state is a major wheat producer) and crop sowing months (indicator for months of the year when fertilizer is applied for kharif rice; indicator for months of the year when fertilizer is applied for rabi wheat). Since planting seasons across India's regions do not coincide for the main crops of rice and wheat, this is a source of variation that may be exploited to establish causal links between water agro-contaminants and child health. Our two stage least squares model is of the standard form where the first stage (written as a function of the identifying instruments only) is:

$$
F_{j t m_{c}}=\gamma_{0}+\gamma_{1}\left(R_{j} \times M^{R}\right)+\gamma_{2}\left(W_{j} \times M^{W}\right)+{ }_{\vartheta_{i j}}
$$

$R_{j}$ and $W_{j}$ denote the largest rice growing states (Andhra Pradesh, Tamil Nadu, West Bengal, and Assam) and wheat growing states (Punjab, Haryana, Gujarat, Uttar Pradesh), respectively. $M^{R}$ and $M^{W}$ 
are indicator variables for months of the year when the rice and wheat crops are sown, respectively. The interaction terms in equation (2) are the identifying instruments; however as discussed in Table 7 below, the first stage in the empirical specifications also includes a full set of (non-identifying) exogenous regressors. The second stage is similar to equation (1) except that $F_{j t m_{c}}$ is replaced by $\widehat{F_{j t m_{c}}}$, its orthogonal component (predicted value) from equation (2).

In this two stage specification, the identifying assumption required for effects to be interpreted as causal is that the instruments satisfy the exclusion restriction (correlated with presence of agrichemicals in water, but conditional on agrichemicals, uncorrelated with child health outcomes), and there are no omitted variables that are both correlated with health outcomes and seasonal levels of water pollution. We present tests of instrument validity below.

\section{Data}

\section{Water Data}

The water quality data are from the Central Pollution Control Board (CPCB) of India, which, as of 2005, monitors inland water quality at 870 stations under two programs: the Global Environment Monitoring System (GEMS) and Monitoring of Indian National Aquatic Resources (MINARS). The monitoring network covers all rivers and their tributaries, and other sources of water such as creeks, wells, tanks, lakes, ponds, and canals. Although CPCB has collected water data from 1978 onwards, they maintain electronic records only from 2005. Computable water quality information on CPCB measures was compiled from two other sources - UNEP GEMS/Water program that computerized CPCB records from 1978 to 2005 for a subset of monitoring stations, and Greenstone and Hanna (2011) that uses electronic water quality data from 1986 to 2005 for a subset of monitoring station (489 stations in 424 cities). Remaining gaps were filled in using information from annual water quality statistics publications obtained from $\mathrm{CPCB}$ (we assumed that the annual average level is the same as the missing 
monthly value for the corresponding state and year) to create our complete monthly-level water quality data which spans 1978-2005. We end at 2005 since that year coincides with the last round of DHS data for India.

CPCB collects detailed water quality statistics on a number of measures. These include information on microbiology (faecal coliform, total coliform), nutrients (ammonia, nitrates, nitrites, nitrogen kjeldahl, phosphates), organic matter (biochemical oxygen demand), major ions (calcium, chloride, fluoride, magnesium, potassium, sodium, sulphates), metals (arsenic, boron, cadmium, lead mercury, zinc), and physical/chemical characteristics of water (alkalinity, dissolved oxygen, hardness, $\mathrm{pH}$, turbidity, temperature). As general controls for water pollution, we include measures of faecal coliform, biochemical oxygen demand (BOD), and dissolved oxygen in all of our models. Greenstone and Hanna (2011) note that these are the most widely used CPCB official water quality controls and have the most consistency in reporting over the years considered. Higher levels of faecal coliform and BOD (the main source of which is industrial pollutants) are associated with more pollution; higher levels of dissolved oxygen are associated with less pollution. Figure 5 reports the trend in the average levels of these measures in our sample. Declines in the log value of faecal coliform and increases in dissolved oxygen suggest some improvement in these water quality measures over time. However, the more than one and half times increase in the level of BOD in the 2000-2005 time period as compared to earlier years indicates that industrial pollutants have contributed to a serious contamination of water in India in recent times.

In addition to general controls for water pollution, we require a measure of the presence of fertilizer agrichemicals in water. Since there is no measure for the presence of fertilizers in the water data, we create a commensurate variable using information on the main chemical components of fertilizers in India. This is accomplished by constructing a dummy variable that indicates the presence 
in water of any of the main fertilizer constituents. ${ }^{8}$ Figure 6 shows the trend in the average presence of fertilizer chemicals in water. It is apparent that agrichemical levels have fallen over time - periods that were closest to the Green Revolution in India were characterized by higher levels of use as compared to more recent years (although fertilizer use has declined, the median year of birth of children in our DHS data is 1991, a time when fertilizer use was still relatively high). Table 1 reports average water pollutant and fertilizer agrichemical levels in the first month and first trimester, demarcated by the three years for which we have demographic data from India - 1992, 1998, and 2005. These estimates indicate that there has been some improvement in dissolved oxygen and some deterioration in terms of BOD (as noted in Figure 5). Table 1 agrichemical estimates are also consistent with the trend for fertilizer agrocontaminants in Figure 6. Next, we discuss our demographic data from India.

\section{Demographic Data}

Child health outcomes, maternal, paternal, and household characteristics are available from three rounds of the Indian National Family Health Survey (NFHS). These are the DHS for India, and in addition to the maternal risk factors and demographic characteristics that are asked of all women between the ages of 15-49, these data contain detailed reproductive histories on year and month of delivery of every child born, information on negative birth outcomes such as stillbirths, abortions and miscarriages, information on birth-weight, and height-for-age (stunting) and weight-for-age (underweight) z scores for children less than age five. Table 2 presents summary statistics of child-specific, woman-specific, husband-specific, household-specific, and state-specific characteristics in our sample,

\footnotetext{
${ }^{8}$ Information on the components of fertilizers is available from India's Department of Fertilizer under the Ministry of Chemicals and Fertilizers (http://fert.nic.in/aboutfert/aboutfertilizers.asp). More specifically, the components (in decreasing order) are nitrogen, nitrates, nitrites, phosphates, potassium, ammonia, iron, sulphates, sodium, magnesium, fluoride, calcium, and chlorides.
} 
differentiated by rounds of the DHS. ${ }^{9}$ In general, there are decreasing trends evident in terms of order of birth and complications in delivery (as proxied by the indicator for caesarian-section deliveries). Across the DHS rounds, women are older and more literate. ${ }^{10}$ Self-employment probabilities for women improve over time as does woman's general health measured by body mass index (BMI).

Husband-specific characteristics in Table 2 show similar trends. Husband's age increases over time as does literacy (measured by a declining proportion of those with no education). Further, household-specific measures reveal that up to three quarters of our sample is rural, there is a declining trend in male headship, about 80 percent of households are Hindu, and between $22-29$ percent belong to the disadvantaged caste group in India (Scheduled Caste/Scheduled Tribes). General infrastructure measures and proxies for wealth also show improvements over time. Access to electricity has increased by about 13 percent from 1992 to 2005, and there have been dramatic increases in ownership of consumer durables such as refrigerators, televisions, and motorcycles. Piped water (a relatively safe source) is the origin of drinking water for only about a third of the sample over time. State-specific measures reveal that per capita state income has increased by about 30 percent over the period of analysis - a substantial increase that may, in part, reflect the 1991 trade, fiscal, and financial liberalization that India underwent and the subsequent rise in the pace of economic growth. Finally, although there is evidence of an increase in average rainfall levels and in the number of malaria cases over the years we examine, average water temperature has remained relatively constant.

\footnotetext{
${ }^{9}$ Information on per-capita net state domestic product and average rainfall by year was obtained from the Economic Organization and Public Policy Program (EOPP) database from the London School of Economics.

${ }^{10}$ For literacy and the dummy for woman's work in farming, fishing, hunting, or logging, the means for 1998 appear skewed in comparison to 1992 and 2005. This is because we have a relatively large number of missing observations in the water quality data leading to imperfect matches between the demographic data and the water information on the basis of state, year, and month in 1998. Since we keep only those with non-missing water quality information for purposes of estimation, literacy and dummy for work in agriculture appear to be off-trend in 1998.
} 
Table 2 describes the exogenous determinants of child health. For purposes of estimation, these measures are merged with water quality data on the basis of each child's state of residence and year and month of conception. Year and month of conception are determined retrospectively using information on year and month of birth of the child, assuming a nine month gestation cycle. ${ }^{11}$ The resulting data set has child health outcomes matched with general water pollution measures in the month of conception, agrichemical presence in the month of conception, and other characteristics described in Table 2. We focus on first trimester impacts since there is evidence that exposure at this juncture in fetal development is most critical. In particular, Manassaram et al. (2006) notes that nitrates and nitrites may travel through the placenta to affect the fetus in the first trimester. The separation of blood circulation between mother and fetus is achieved only from the beginning of the second trimester of pregnancy (fourth month) when the placental membrane becomes adequately developed. We begin by considering the effect of exposure to reproductive toxins in the month of conception on various measures of infant and child health; later we report results that consider the effect of first trimester averages of the presence of fertilizer agrichemicals in water on infant mortality, neo-natal mortality, and post-natal mortality.

We turn next to a description of the child outcomes we study. These are reported in Table 3 and include infant mortality (child was born alive but died at or less than eleven months of age), neo-natal mortality (child was born alive but died in the first month of life), and post-natal mortality (child was born alive but died between the first and eleventh month of life). In utero exposure to toxins is believed to have the strongest impact on neo-natal mortality; post-natal mortality is more likely to result from diseases (diarrhea), poor nutrition, child living circumstances/environment, or accidents. Further, recent studies have noted that male fetuses are more susceptible to environmental insults (Garry et al. 2002, Sanders and Stoecker 2011), and have low immune responses and weak resistance to infection

\footnotetext{
${ }^{11}$ Alternative specifications using a 10 month gestation cycle (40 weeks) did not result in appreciably different results.
} 
(Drevenstedt et al. 2008). To see whether this pattern holds for India, we measure impacts of agrichemicals in water on child gender. Birth-weight, a widely used measure of immediate and long-run health for children is analyzed as well along with standardized evaluators of stunting (height-for-age $\mathrm{z}$ score for children less than five years) and being under-weight (weight-for-age $\mathrm{z}$ scores for children less than five years). ${ }^{12}$ Summary statistics for these outcomes is presented in Table 3.

Estimates in Table 3 reveal that although infant mortality has declined in our sample, most of this has come from declines in post-natal mortality. The proportion of male children has remained somewhat stable, whereas birth-weight has shown a marginal improvement over time. The height-forage $\mathrm{z}$ score shows that the average Indian child was stunted (the threshold for stunting is less than 2 standard deviations from the mean) in 1992, but there has been a gradual improvement in this measure from then on. Similarly, the average Indian child scored well below conventionally accepted threshold levels for adequate nutrition in terms of the weight-for-age measure in 1992. Again, there has been improvement in this measure especially from 1992 to 1998.

We conclude this section by describing the estimates in Tables $4-6$. Table 4 shows pairwise correlation coefficients between the presence of fertilizer agrichemicals in the month of conception and the outcomes examined. These coefficients indicate that fertilizer chemicals are significantly positively correlated with infant mortality (both neo-natal and post-natal) and low birth-weight (using the conventionally accepted threshold of 2500g), and significantly negatively correlated with gender being male and height-for-age and weight-for-age $\mathrm{z}$ scores. Table 5 reports that birth weight is positively correlated with post-birth health measures on height and weight. Hence, low birth-weight children in India are likely to continue to score poorly on these post-birth health indicators as of age five. This is in contrast to literature from the developed world which suggests that after-birth interventions may be able

\footnotetext{
${ }^{12}$ Deaton and Dreze (2009) note that for Indian children, weight-for-age z scores are better suited measures of being under-weight (as opposed to wasting).
} 
to ameliorate some of the long term negative health implications of low birth-weight (Almond and Currie 2010). Finally, estimates in Table 6 reveal that it is not just agrichemicals in the first month that are important. Aggregate trimester averages of fertilizer presence in water also exert harmful consequences on all outcomes considered. ${ }^{13}$

\section{Results}

\section{Ordinary Least Squares}

We begin the discussion of results by reporting ordinary least squares (OLS) models that do not correct for measurement error in the endogenous variable, fertilizer agrichemicals. This corresponds to the empirical specification in equation (1) and the OLS results are reported in Appendix Tables 1 and 2. As is well known, classical measurement error leads to attenuation bias (Greene 1993). This is consistent with the size of the coefficients on the agrichemicals variable in these tables which are mostly biased towards zero and measured imprecisely. Not correcting for measurement error also leads to counter-intuitive results as in the last column of Appendix Table 2 where fertilizers are found to increase the weight-for-age $\mathrm{z}$ score. Having demonstrated bias and inefficiency in the OLS results, we turn next to our preferred specification, the two stage least squares (TSLS) instrumental variables model.

\section{Two Stage Least Squares}

Results from the first stage in equation (2) are reported in Table 7. The three columns of Table 7 show results where the indicator of the presence of fertilizer agrichemicals in the first month is averaged at the state, year, and month level. ${ }^{14}$ The wheat instrument is significant whereas the rice instrument is

\footnotetext{
${ }^{13}$ The size of the correlation coefficients are consistent with expectations - infant mortality and child gender are most affected by first trimester exposure whereas third trimester exposure has the largest effect on birth-weight (bio-medical literature indicates that babies gain the most weight in the third trimester).

${ }^{14}$ Without this averaging, the dependent variable in the first stage is non-linear. Angrist and Krueger (2001) show that estimating a two-stage model where the first stage is non-linear is suspect since the model is essentially identified from the non-linearity in the first stage.
} 
measured imprecisely in the first column. The wheat instrument has a strong positive effect on the endogenous variable consistent with our hypothesis that agrichemical levels peak in these states during the application months. Results for the rice instrument are less clear-cut echoing our earlier point that the rice crop cycle in India often does not have cleanly demarcated fertilizer application times. The Fstatistic for the identifying instruments in the first column of Table 7 is above 10, the rule-of-thumb threshold value for sufficient level of strength. This is consistent with the corresponding $p$-value which strongly rejects the null hypothesis that the identifying instruments are jointly insignificant. The second column adds child, woman, husband, and state-specific characteristics to those in the first column of Table 7 and explains about 7.3 percent of the variation in fertilizer presence. The coefficient on the wheat instrument is as expected but the rice instrument indicates that average fertilizer presence is lower in these states during sowing months. A part of this may be due to time and state trends as discussed below. The F-statistic in column 2 is stronger than in column 1 of Table 7 in indicating that the identifying instruments have sufficient power.

Given the nature of these data, it is likely that the effects of the rice and wheat instruments are contaminated with time and state-level heterogeneity. A way to control for this is to include month and year of conception dummies, region dummies, and interactions of year of conception and region dummies. The third column of Table 7 shows results with the inclusion of these additional controls. The wheat instrument is as before and along with the rice dummy and other included variables now explains about 20 percent of the variation in agrichemical presence. The effect of the rice instrument underlines what we note above on the absence of specific fertilizer application times in the annual growing cycle of this crop. Further, the significant negative effect of the rice instrument in comparison to its reference group may reflect our focus on the kharif season which coincides with the arrival of the monsoons in India. As noted in Ebenstein et al. (2011), rainfall may dilute the presence of 
agrichemicals by supplying quantities of clean water. The F-statistic on the identifying instruments in the third column of Table 7 remains comfortably above the rule-of-thumb value for sufficient strength. The results in Table 7 indicate that the wheat instrument in particular is a significant determinant of the seasonal presence of fertilizer agrichemicals in water. Effects for the rice instrument are more ambiguous; however, we include it in the first stage since rice is as important a crop as wheat in India.

Our main results from the second stage of the TSLS model are presented in Tables 8 and 9. Before we discuss these results, we note that in order to implement a linear instrumental variables model, non-linear outcomes (infant mortality, neo-natal mortality, post-natal mortality, and male gender) are averaged to the state, year, and month levels. Linear TSLS is the preferred econometric method since it has the added advantage of reporting tests of instrument validity. Moreover, as noted above, the TSLS models include separate controls for general measures of water quality - faecal coliform, BOD, and dissolved oxygen. This is necessary to ensure that their absence does not bias the effect of the agrichemical variable. ${ }^{15}$

Table 8 reports the instrumental variables results for the impact of average fertilizer presence in water in the month of conception on outcomes that are most susceptible in the first trimester. We begin by noting that a test of over-identifying restrictions (Hansen's $J$ statistic) which evaluates the joint null hypothesis that the instruments are valid (that is, not correlated with the error term and that the identifying instruments are correctly excluded from the estimated second stage), cannot be rejected at the 5 percent level in three of the four models of Table 8. The first column reports that fertilizer

\footnotetext{
${ }^{15}$ We should note that exclusion of the general water pollutant variables can result in bias through omitted variables even if there is little overlap between these measures of water quality and agrichemicals. The main source of faecal coliform and BOD is human presence and industrial pollutants (which are composed of a mostly non-overlapping set of different chemicals such as arsenic and mercury), respectively. Thus agrichemicals from fertilizer have little feedback effects on BOD and vice versa. However, fertilizer levels might be correlated with dissolved oxygen as noted in Ebenstein et al. 2011. We retain all three water pollutant measures in our specifications since these are widely used measures of general water quality in India (Greenstone and Hanna 2011).
} 
agrichemicals have a strong positive impact on infant mortality. Estimates indicate that a unit increase in the average measure of such agro-toxins increases average infant mortality by 0.09 units. This means that for a 10 percent increase in the average level of agrichemicals in water, average infant mortality increases by 11.26 percent. The second column of Table 8 shows that much of this effect comes from the adverse consequences of agro-contaminants on neo-natal mortality. The coefficient in this column indicates that for a 10 percent increase in the average level of fertilizer in water, average neo-natal mortality increases by 14.62 percent. Fertilizer effect on male children has the expected sign but is measured without significance in the last column of Table 8. Finally, other measures of water pollution (faecal coliform, BOD, and dissolved oxygen) that are included in the models are mostly insignificant except for the last column where the level of faecal coliform has the expected impact on child gender.

Table 9 reports the instrumental variables results for the impact of average fertilizer presence in water in the month of conception on other child health outcomes. Again, a test of over-identifying restrictions indicates that our instruments are valid. As expected, agrichemicals have negative influences on birth weight and height-for-age and weight-for-age z scores. ${ }^{16}$ In particular, the coefficient in the first column of Table 9 indicates that for a unit increase in average fertilizer presence in water, birth-weight declines by 0.95 kilograms although this is not significantly different from zero. Focusing on the height-for-age $\mathrm{z}$ score which is considered a good comprehensive measure of child health in India (Deaton and Dreze 2009), estimates indicate that for a 10 percent increase in the level of agrichemical toxins in water, height-for-age $\mathrm{z}$ scores decline by about 0.14 standard deviations. This is a significant but not overly large effect. Other general water pollution measures included in the models have the expected effects and are measured with more precision in comparison to Table 8 . Faecal coliform in particular has consistent detrimental effects on height-for-age and weight-for-age in Table 9.

\footnotetext{
${ }^{16}$ Birth-weight is less likely to be recorded in rural areas or in cases where the woman delivered at home. This may contribute to the relatively fewer number of observations for this variable in Table 9.
} 
Among the remaining water pollutant indicators, dissolved oxygen has the expected beneficial effect on birth-weight.

The remaining two tables in the results section consider different specifications of the main TSLS results in Tables 8 and 9. Table 10 reports disaggregated runs for neo-natal mortality for the following sub-samples: uneducated versus educated women, rural versus urban areas, and poor versus rich households. It is immediately apparent that although the negative consequence of fertilizer toxins is evident across both education groups, the magnitude of the adverse impact is more than double in size for women with no schooling. Although educated women are also exposed to agrichemical toxins perhaps through drinking water, these results indicate that they are able to engage in behaviors that counter-act some of the negative in utero consequences of exposure to tainted water. Next, in keeping with increased exposure from agriculture, the harmful impact of agrichemicals on neo-natal mortality is most evident in rural as compared to urban areas. Finally, using proxy measures of wealth to differentiate between poor and rich households, estimates in Table 10 reveal that it is the poor who are particularly susceptible to the detrimental impacts of agro-contaminants. ${ }^{17}$ The remaining general water pollutant measures are mostly insignificant. The results in Table 10 underscore that the negative health implications of fertilizer agrichemicals are strongest among the most vulnerable - children of uneducated poor women who live in rural India.

Finally, Table 11 reports the child health impacts of average first trimester exposure to agrichemicals in water (average of exposure in the first, second, and third months). The aim is to investigate whether exposure beyond the month of conception has added effects on infant and child well-being. We focus only on measures that are most impacted in the first trimester - infant mortality and its components. It is clear from the results in Table 11 that there is some added effect on infant

\footnotetext{
${ }^{17}$ Rich households are those who own refrigerators, televisions, and motorcycles. The poor own none of these assets/consumer durables.
} 
mortality from exposure in the second and third month beyond the first month. The magnitude of the agrichemical variable on infant mortality is somewhat larger than the corresponding value in Table 8, and this is true for neo-natal mortality also. ${ }^{18}$ In comparison to Table 8 , results continue to remain insignificant for post-natal mortality in Table 11. Other indicators of general water quality in Table 11 continue to remain mostly insignificant.

The instrumental variables results in Tables $8-11$ demonstrate that the presence of fertilizer agrichemicals in water in the month of conception has statistically significant negative impacts on a broad range of child health measures. It is striking that exposure in the first month has implications for health measures that are believed to be most affected beyond the first trimester - significant effects on height-for-age and weight-for-age z scores. Disaggregated runs indicate that adverse consequences are most evident among susceptible populations - children of poor uneducated women in rural areas of India. Furthermore, there is evidence that aggregate exposure to fertilizer agrichemicals throughout the first trimester has a somewhat large negative impact on infant health outcomes as compared to exposure in only the first month. We conduct robustness checks for these results in the following section.

\section{Robustness Checks}

The checks conducted in this section of our research ascertain that the identifying instruments have no indirect effects on child health measures through their correlation with omitted variables. For this to be the case the omitted variable(s) would have to vary seasonally and by agricultural region in the same way that fertilizer concentrations vary seasonally and across regions. Weather related natural phenomena such as average rainfall and water temperature as well as the incidence of diseases such as malaria may satisfy these conditions and we verify the validity of our instruments with respect to these

\footnotetext{
${ }^{18}$ Although the estimates in Table 11 are larger in magnitude than corresponding estimates in Table 8, we cannot reject that month of conception and first trimester impacts are statistically equivalent. These tests are available on request.
} 
variables. ${ }^{19}$ In particular, rain and temperature may have independent effects on child health measures such as infant mortality even conditional on rice and wheat instruments (for example, the likelihood of infant mortality may rise when temperatures are unseasonably warm or when the rains fail as noted in Burgess et al. 2011). The incidence of disease may also vary seasonally and by regions and have direct effects on child health through influencing mother's health in the year of conception. The overidentification tests in Table 8 provide evidence that the instruments satisfy the exclusion restriction. However, as an additional test, average rainfall by state and year, average water temperature by state, year, and month, and the number of malaria cases by state and year were separately included as regressors in the second stage of the models in Table 8. These results along with updated overidentification tests are presented in Table 12. It is evident that the inclusion of rainfall, temperature, or log number of malaria cases does not change the main results in Table 8 (we lose a few observations because of missing rain and temperature data and somewhat more observations because of missing malaria data). The magnitude on fertilizer agrichemicals in response to the inclusion of weather variables is comparable in its impact on infant mortality in Tables 8 and 12 and still significant. In terms of neo-natal mortality, agrichemical effects are also comparable and still measured with precision. Inclusion of malaria cases in the second stage significantly increases the magnitude of the impact of agrichemical toxins in the month of conception on infant mortality and neo-natal mortality. Further, conditional on the incidence of malaria in the year of conception, water toxins are now found to have a significant effect on post-natal mortality. Hence, inclusion of a measure for disease in the second stage serves to further strengthen the effect of agro-toxins on child health suggesting that its absence led to a

\footnotetext{
${ }^{19}$ We use water temperature as a proxy measure of land surface temperature. Land temperature for allIndia by state, year, and month are difficult to obtain, but our water data contains water temperature at the detailed level we seek. It has been noted that water temperature is correlated to air temperature albeit not perfectly (Pilgrim et al. 1998). Information on malaria cases at the state-level was collected from http://infochangeindia.org/health/statistics/statewise-number-of-malaria-cases-and-deaths-from2005-2008.html. Accessed on Nov. 24, 2011.
} 
conservative bias in the corresponding estimates reported in Table 8. These tests in Table 12 further corroborate the results reported in Table 8 by demonstrating that the instruments are randomly assigned.

\section{Conclusion and Implications for Policy}

This analysis aims to broaden our understanding of the health effects of fertilizer use in India on a section of the population that is particularly vulnerable to environmental abuses - infants and children below the age of five. Although economists have recognized the importance of water quality in reducing mortality (Cutler et al. 2006), to the best of our knowledge, no rigorous evaluation of health impacts of fertilizer agrichemicals in water that is attentive to the seasonal aspect of agriculture has been conducted using data from a poor country like India. We seek to rectify this omission.

Using data on water pollution from monitoring stations run by India’s Central Pollution Control Board combined with data on the health outcomes of infants and children from the 1992-93, 1998-99, and 2005-06 Demographic and Health Surveys of India, our identification strategy exploits the increase in fertilizer use over time in India, the differing timing of the planting seasons across India's states, and the differing seasonal prenatal exposure of infants and children to agrichemicals to identify the impact of water contamination on various measures of child health. We correct for possible measurement error in agrichemicals using indicators of major rice and wheat producing states in India interacted with indicators of the planting seasons of these crops as identifying instruments. First stage results reveal that wheat in particular is associated with elevated levels of agro-contaminants in water. This is consistent with the fact that the Green Revolution in India began in the wheat growing regions of the north.

Our TSLS analysis of the effects of agrichemicals on different measures of child health provides notable results. We find that a 10 percent increase in the average level of fertilizer chemicals in water in the month of conception increases the likelihood of infant mortality by about 11 percent. Our results indicate that neo-natal mortality is particularly susceptible to agro-contaminants in water as a 10 percent 
increase in water toxins from fertilizers is associated significantly with about a 15 percent increase in mortality within the first month. These are relatively large effects but in-keeping with the findings in Chay and Greenstone (2003), Cutler and Miller (2005), and Galiani et al. (2005). ${ }^{20}$ Disaggregated runs reveal that the harmful consequences are most evident for vulnerable populations - children of rural uneducated poor Indian women. We employ alternate specifications to establish the robustness of results that are at most risk in early pregnancy: infant mortality, neo-natal and post-natal mortality.

The findings of this research highlight the tension between greater use of fertilizer to increase yields and the negative child health effects that result from such use. In order to guarantee greater security in child health, it may be necessary to focus on generating only reasonable yield amounts by curtailing the use of synthetic chemical additives. Strategies that assist in circumventing the harmful effects of water toxins while still ensuring a sufficient level of output include increasing reliance on organic fertilizers (compost, manure), and adoption of alternative farming techniques that improve soil productivity without the application of inorganic supplements (crop-rotation). Implementation of programs that seek to raise consciousness and bolster the nutrition of mothers who are most exposed may also counteract some of the negative impacts. Finally, early health intervention programs that provide nutrient supplements to low-birth weight babies may be an ameliorative proposition. These strategies are likely to be costly for cash-strapped developing countries such as India. However, their adoption may prove vital to slowing the unintended health consequences of the widespread use of inorganic fertilizers in Indian agriculture. We study the effects of fertilizer agrichemicals in water on infant and child health to draw awareness to this subject, and to contribute to an area of economic research which has previously not been examined in detail in the context of a low-income country.

\footnotetext{
${ }^{20}$ In particular, Cutler and Miller (2005) argue that the adoption of clean water technologies such as filtration and chlorination was responsible for up to 75 percent of infant mortality reduction in early twentieth century America. Galiani et al. (2005) conclude that privatization of water supply in lowincome areas of Argentina reduced the mortality of children under age 5 by 26 percent.
} 


\section{References}

Almond, Douglas and Janet Currie (2010). “Human Capital Development Before Age Five," Handbook of Labor Economics, Vol. 4B (Elsevier): 1315-1486.

Almond, Douglas, Lena Edlund, and Mårten Palme (2009). “Chernobyl’s Subclinical Legacy: Prenatal Exposure to Radioactive Fallout and School Outcomes in Sweden," Quarterly Journal of Economics 124(4): 1729-1772.

Angrist, Joshua D., and Alan B. Krueger. 2001. "Instrumental Variables and the Search for Identification: From Supply and Demand to Natural Experiments". Journal of Economic Perspectives 15(4): 69-85.

Bardhan, Pranab and Dilip Mookherjee (2011), "Subsidized Farm Input Programs and Agricultural Performance: A Farm-Level Analysis of West Bengal's Green Revolution, 1982-1995," American Economic Journal: Applied Economics 3(4): 186-214.

Burgess, Robin, Olivier Deschenes, Dave Donaldson, and Michael Greenstone (2011), "Weather and Death in India," Mimeo.

Carr, Genevieve M., and James P. Neary (2008), "Water Quality for Ecosystem and Human Health," $2^{\text {nd }}$ Edition, United Nations Environment Program Global Environment Monitoring System (GEMS)/Water Program.

Chakravarti, A.K (1973), "Green Revolution in India," Annals of the Association of American Geographers 63(3): 319-330.

Chand, Ramesh (2001), "Wheat Exports: Little Gain,” Economic and Political Weekly 36(25): 22262228.

Chattopadhay, G.N., B.C. Roy, and R. Tirado (2009). Subsidising Food Crisis. Bangalore: Greenpeace.

Chay, Kenneth Y. and M. Greenstone (2003). "The Impact of Air Pollution on Infant Mortality: Evidence from the Geographic Variation in Pollution Shocks Induced By a Recession," Quarterly Journal of Economics 118(3): 1121-1167.

Currie, Janet and Reed Walker (2011), “Traffic Congestion and Infant Health: Evidence from E-Z Pass," American Economic Journal: Applied Economics 3(1): 65-90.

Cutler, D., and G. Miller (2005). "The Role of Public Health Improvements in Health Advances: The Twentieth Century United States," Demography 42(1): 1-22.

Cutler, D., A. Deaton, and A. Lleras-Muney (2006). “The Determinants of Mortality,” Journal of Economic Perspectives 20(3): 97-120.

Deaton, Angus and Jean Drèze (2009), "Food and Nutrition in India: Facts and Interpretations," Economic \& Political Weekly 44(7): 42-65. 
Drevenstedt, Greg, E. Crimmins, S. Vasunilashorn, and C. Finch (2008). "The Rise and Fall of Excess Male Infant Mortality," Proceedings of the National Academy of Sciences 105(13): 5016-5021.

Duflo, E., M. Greenstone, and R. Hanna (2007). "Indoor Air Pollution, Health and Economic WellBeing," Mimeo.

Ebenstein, Avraham, Zhang, Jian, McMillan, Margaret, and Kevin Chen (2011). "Chemical Fertilizer and Migration in China," NBER Working Paper 17245.

Garry, V.F, M.E. Harkins, L.L. Erickson, L.K. Long-Simpson, S.E. Holland, and B.L. Burroughs (2002). "Birth Defects, Season of Conception, and Sex of Children Born to Pesticide Applicators Living in the Red River Valley of Minnesota, USA," Environment and Health Perspectives 110 (Supp. 3): 441-449.

Greene, William (1993). Econometric Analysis. $2^{\text {nd }}$ Edition. New York: Macmillan Publishing Company.

Greenstone, Michael and Rema Hanna (2011), "Environmental Regulations, Air and Water Pollution, and Infant Mortality in India," NBER Working Paper 17210.

Heeren, G.A., J. Tyler, and A. Mandeya (2003). "Agricultural Chemical Exposures and Birth Defects in the Eastern Cape Province, South Africa: A Case-Control Study," Environmental Health: A Global Access Science Source: 2-11.

Manassaram, Deana M., Lorraine C. Backer and Deborah M. Moll (2006). "A Review of Nitrates in Drinking Water: Maternal Exposure and Adverse Reproductive and Developmental Outcomes," Environmental Health Perspectives 114(3): 320-327.

Pilgrim, John, Fang, Xing, and Heinz Stefan (1998). "Stream Temperature Correlations with Air Temperature in Minnesota: Implications for Climate Warming," Journal of the American Water Resources Association 34(5): 1109-1121.

Pitt, M., M. Rosenzweig, and M.N. Hassan (2006). "Sharing the Burden of Disease: Gender, the Household Division of Labor and the Health Effects of Indoor Air Pollution," Mimeo.

Restropo, M., N. Monoz, N. Day, J. Parra, L. de Romero, and X. Nguyen-Dinh (1990). "Prevalence of Adverse Reproductive Outcomes in a Population Occupationally Exposed to Pesticide in Colombia," Scandinavian Journal of Work, Environmental, and Health 16(4): 232-238.

Sanders, Nicholas J. and Charles F. Stoecker (2011), "Where Have All the Young Men Gone? Using Gender Ratios to Measure Fetal Death Rates,” NBER Working Paper 17434.

Sen, Amartya (1977), "Starvation and Exchange Entitlements: A General Approach and its Application to the Great Bengal Famine," Cambridge Journal of Economics 1:33-59.

Tewatia, R.K., and T.K. Chanda (2005). "Fertilizer Use by Crop,” in Fertilizer Use by Crop in India. Rome: Food and Agriculture Organization of the United Nations.

Winchester, P.D., J. Huskins, and J. Ying (2009). "Agrichemicals in Surface Water and Birth Defects in the United States," Acta Paediatrica 98: 664-669. 
Figure 1: Impact of the Green Revolution on rice and wheat yields.

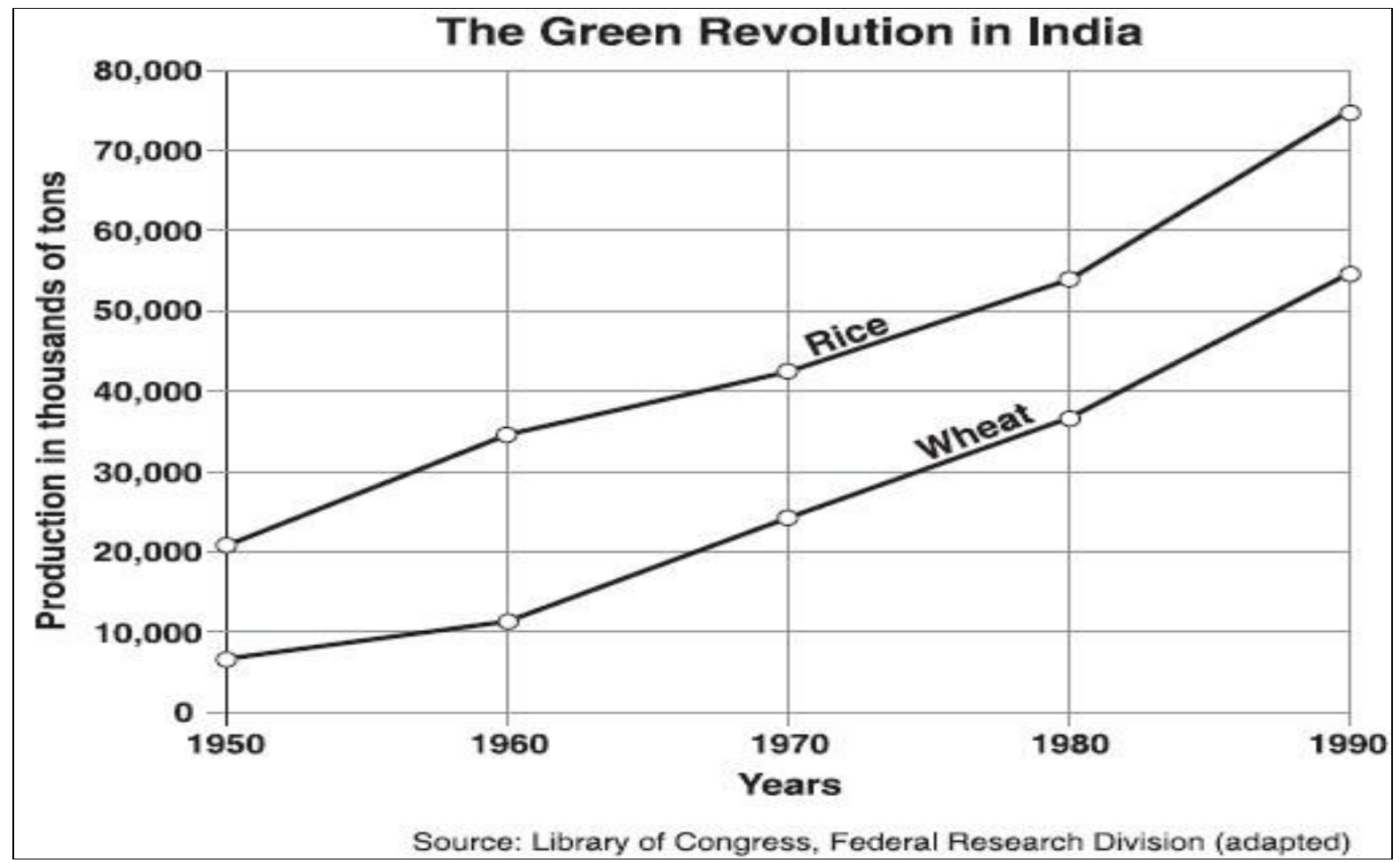

Figure 2: Trend in consumption of NPK fertilizer in India.

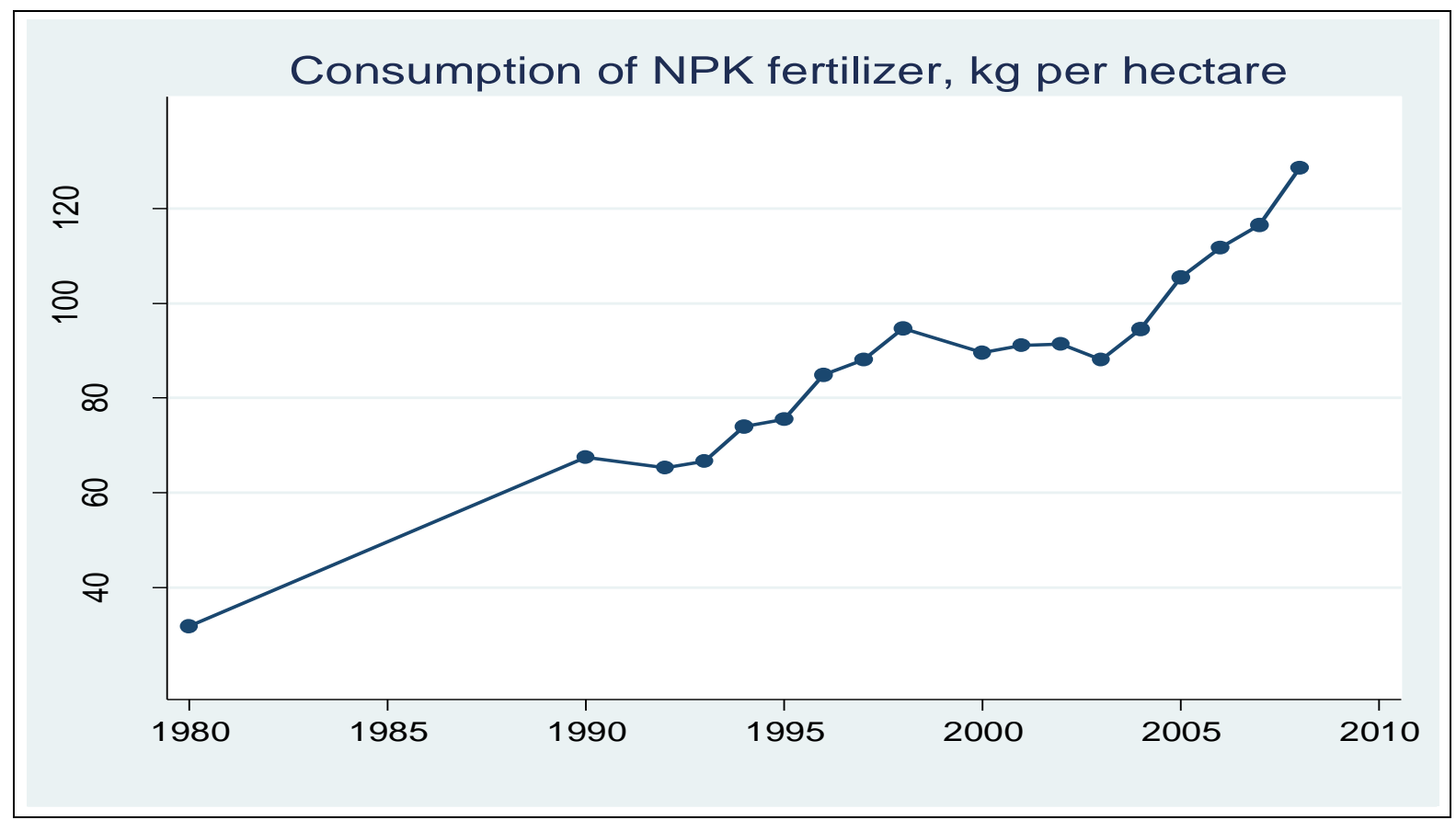

Source: Statistical abstract of India. Various years. 
Figure 3: Cross-country comparison of the consumption of nitrogen from 1980-1996.

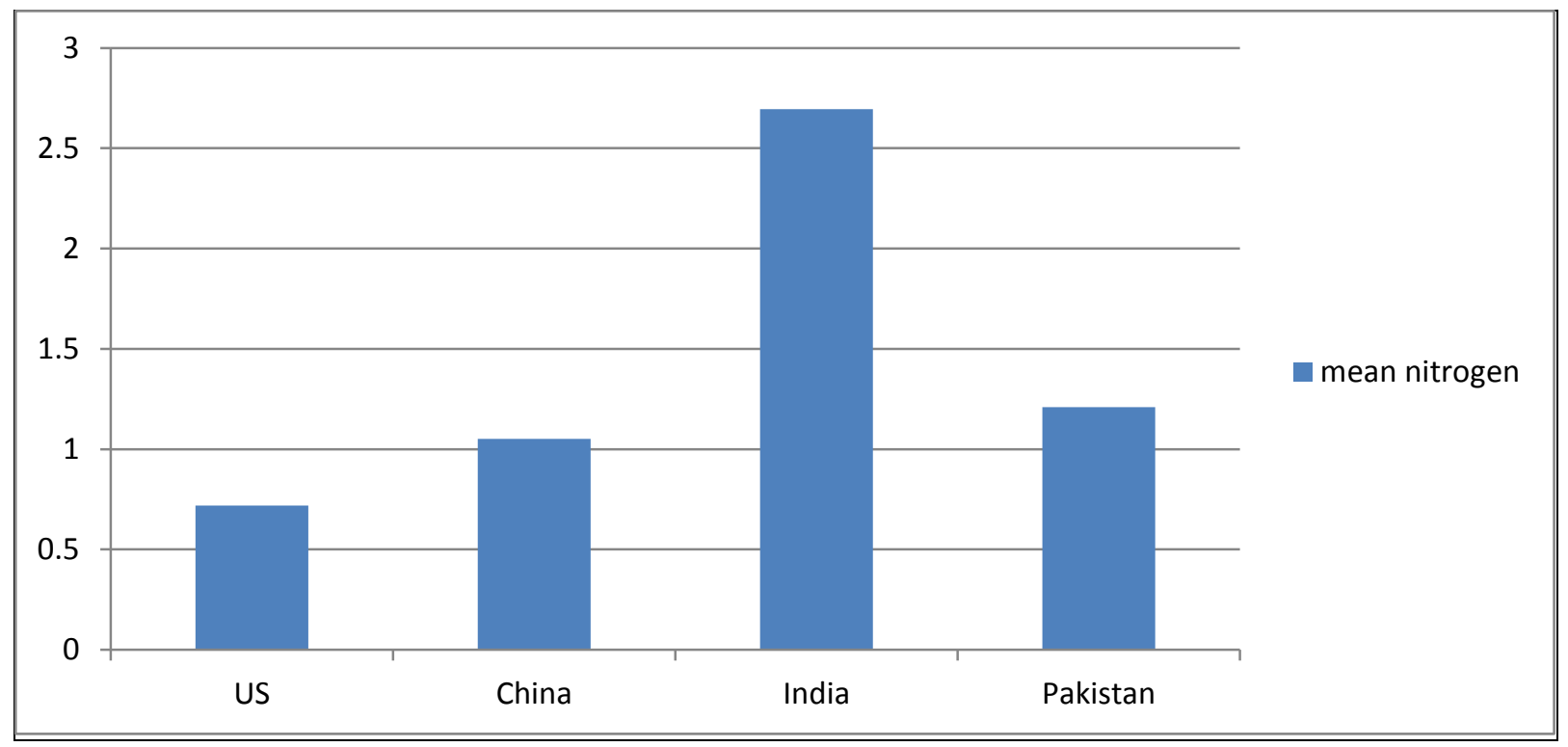

Source: GEMStat global water quality database. Nitrogen is measured as the sum of nitrates and nitrites. Available at: http://gemstat.org/queryrgn.aspx. Accessed on October 24, 2011.

Figure 4: Mean nitrogen concentration in water by month from 1978-2005.

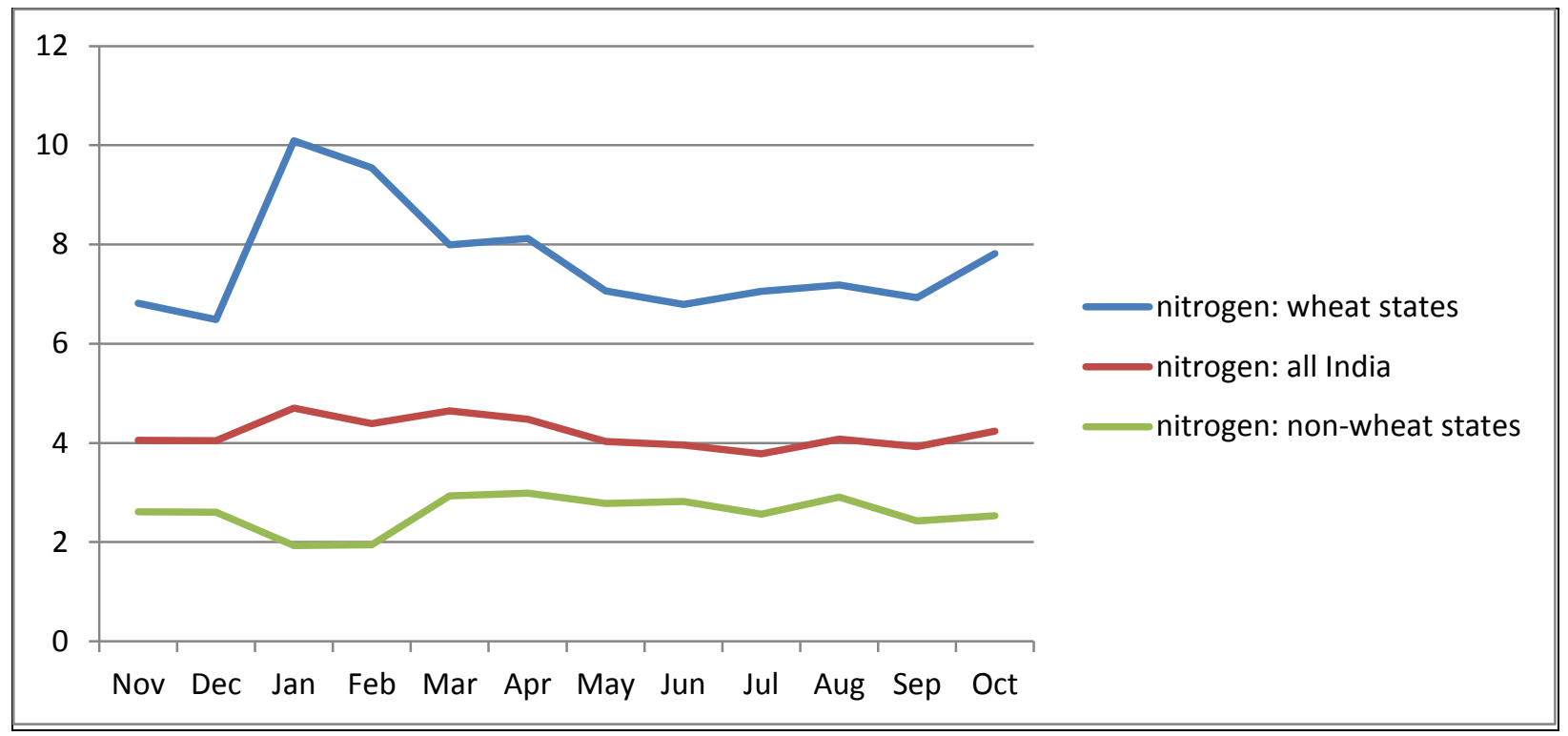

Notes: Authors' calculations. Wheat states include Punjab, Haryana, Gujarat, and Uttar Pradesh. Nitrogen is measured as nitrogen kjeldahl. 
Figure 5: Trend in general water pollution measures over time.

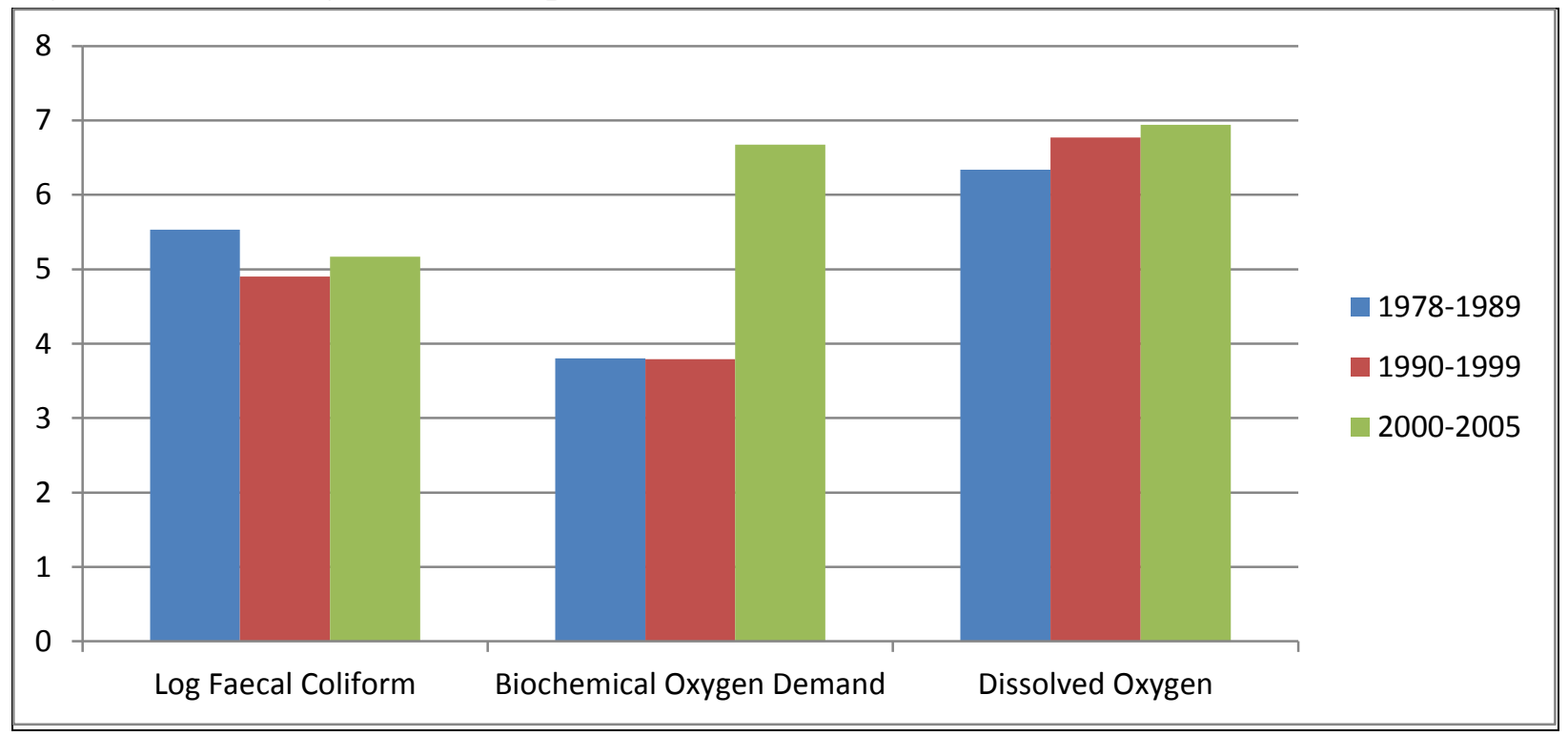

Notes: Author's calculations. Figure shows mean level over all available states for each of the three time spans considered. Faecal coliform is measured in most probable number (MPN) per 100 milliliters (ml), biochemical oxygen demand is measured in milligrams (mg) per liter (l), and dissolved oxygen is measured in $\mathrm{mg} / \mathrm{l}$.

Figure 6: Trend in presence of fertilizer agrichemicals in water over time.

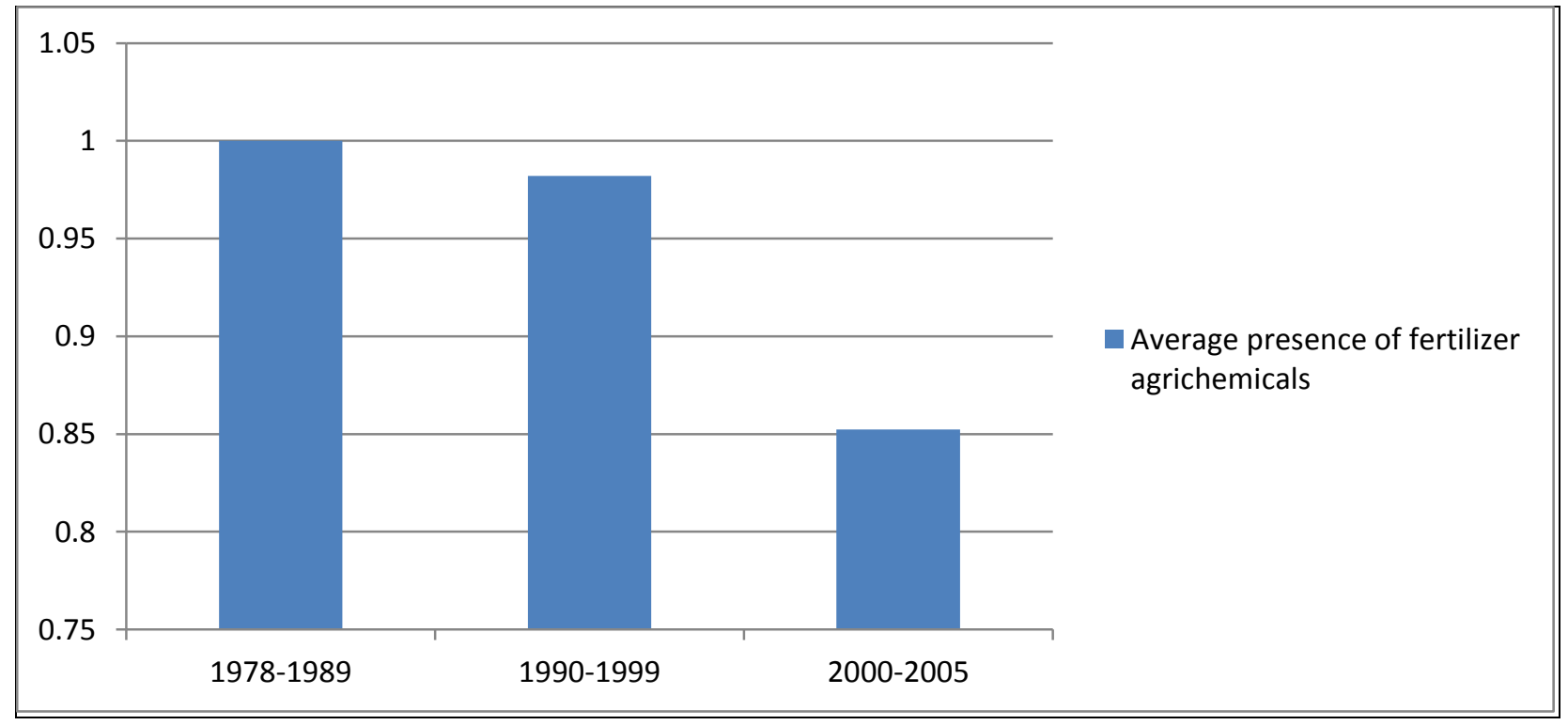

Notes: Author's calculations. Table reports mean of the dummy for the presence of fertilizer agrichemicals in water over all available states for each of the three time spans considered. 
Table 1: Means and standard deviations of general water pollutants and presence of fertilizer agrichemicals by year.

\begin{tabular}{|c|c|c|c|}
\hline Pollutant/Chemical & 1992 & 1998 & 2005 \\
\hline \multicolumn{4}{|l|}{ General water pollutants } \\
\hline Log of faecal coliform & -2.301 & -2.301 & -2.302 \\
\hline \multirow[t]{2}{*}{ in month of conception } & $(0.026)$ & $(0.019)$ & $(0.014)$ \\
\hline & $\mathrm{N}=73735$ & $\mathrm{~N}=112938$ & $\mathrm{~N}=143017$ \\
\hline Log of the first trimester & -4.363 & -4.405 & -4.397 \\
\hline \multirow[t]{2}{*}{ average of faecal coliform } & $(0.750)$ & $(0.663)$ & $(0.594)$ \\
\hline & $\mathrm{N}=72322$ & $\mathrm{~N}=110389$ & $\mathrm{~N}=140755$ \\
\hline Log of biochemical oxygen & -4.356 & -4.350 & -4.330 \\
\hline \multirow[t]{2}{*}{ demand in month of conception } & $(0.218)$ & $(0.223)$ & $(0.273)$ \\
\hline & $\mathrm{N}=83452$ & $\mathrm{~N}=129353$ & $\mathrm{~N}=157483$ \\
\hline Log of the first trimester average & -3.355 & -3.337 & -3.290 \\
\hline \multirow[t]{2}{*}{ of biochemical oxygen demand } & $(0.555)$ & $(0.555)$ & $(0.622)$ \\
\hline & $\mathrm{N}=83219$ & $\mathrm{~N}=128783$ & $\mathrm{~N}=156805$ \\
\hline Log of dissolved oxygen in & -4.140 & -4.121 & -4.105 \\
\hline \multirow[t]{2}{*}{ month of conception } & $(0.105)$ & $(0.097)$ & $(0.089)$ \\
\hline & $\mathrm{N}=83261$ & $\mathrm{~N}=129630$ & $\mathrm{~N}=157806$ \\
\hline Log of the first trimester average & -0.529 & -0.475 & -0.428 \\
\hline \multirow[t]{2}{*}{ of dissolved oxygen } & $(0.283)$ & $(0.249)$ & $(0.215)$ \\
\hline & $\mathrm{N}=82810$ & $\mathrm{~N}=129283$ & $\mathrm{~N}=157571$ \\
\hline \multicolumn{4}{|l|}{ Fertilizer agrichemicals } \\
\hline \multirow{3}{*}{$\begin{array}{l}\text { Dummy for presence of fertilizer } \\
\text { chemicals in month of conception }\end{array}$} & 1.000 & 0.997 & 0.957 \\
\hline & $(0.000)$ & $(0.054)$ & $(0.202)$ \\
\hline & $\mathrm{N}=83899$ & $\mathrm{~N}=130222$ & $\mathrm{~N}=158393$ \\
\hline \multirow{3}{*}{$\begin{array}{l}\text { Average of dummy for presence } \\
\text { of fertilizer in the first trimester }\end{array}$} & 1.000 & 0.997 & 0.957 \\
\hline & $(0.000)$ & $(0.048)$ & $(0.181)$ \\
\hline & $\mathrm{N}=83899$ & $\mathrm{~N}=130222$ & $\mathrm{~N}=158393$ \\
\hline
\end{tabular}

Notes: Weighted to national level with weights provided by the DHS. Standard deviations reported in parentheses. Faecal coliform is measured in MPN/100 ml units, biochemical oxygen demand is measured in $\mathrm{mg} / \mathrm{l}$ units, and dissolved oxygen is measured in $\mathrm{mg} / \mathrm{l}$ units. "N" denotes number of observations. 
Table 2: Means and standard deviations of exogenous characteristics by year.

\begin{tabular}{|c|c|c|c|}
\hline Variables & 1992 & 1998 & 2005 \\
\hline \multicolumn{4}{|l|}{ Child-specific } \\
\hline \multirow[t]{2}{*}{ Order of birth } & 3.124 & 2.966 & 2.759 \\
\hline & $(2.059)$ & $(1.941)$ & $(1.814)$ \\
\hline \multirow[t]{2}{*}{ Dummy for child was nursed } & 0.946 & 0.614 & 0.949 \\
\hline & $(0.227)$ & $(0.487)$ & $(0.219)$ \\
\hline Dummy for child was delivered & 0.204 & 0.165 & 0.082 \\
\hline by caesarian section & $(0.403)$ & $(0.372)$ & $(0.275)$ \\
\hline \multicolumn{4}{|l|}{ Woman-specific } \\
\hline \multirow[t]{2}{*}{ Woman's age } & 29.326 & 31.424 & 33.771 \\
\hline & $(6.537)$ & $(6.956)$ & $(7.401)$ \\
\hline \multirow{2}{*}{$\begin{array}{l}\text { Number of years since first } \\
\text { marriage }\end{array}$} & 13.036 & 14.832 & 16.827 \\
\hline & $(6.690)$ & $(7.171)$ & $(7.652)$ \\
\hline \multirow[t]{2}{*}{ Dummy for woman is literate } & 0.289 & 0.145 & 0.363 \\
\hline & $(0.453)$ & $(0.353)$ & $(0.481)$ \\
\hline \multirow{2}{*}{$\begin{array}{l}\text { Dummy for woman works in } \\
\text { farming, fishing, hunt. or logging }\end{array}$} & 0.230 & 0.645 & 0.114 \\
\hline & $(0.421)$ & $(0.478)$ & $(0.318)$ \\
\hline \multirow{2}{*}{$\begin{array}{l}\text { Dummy for woman is self- } \\
\text { employed }\end{array}$} & 0.086 & 0.115 & 0.144 \\
\hline & $(0.280)$ & $(0.319)$ & $(0.351)$ \\
\hline \multirow{2}{*}{$\begin{array}{l}\text { Dummy for woman works at } \\
\text { home }\end{array}$} & 0.157 & 0.163 & 0.178 \\
\hline & $(0.363)$ & $(0.369)$ & $(0.382)$ \\
\hline \multirow[t]{2}{*}{ Woman's body mass index } & & 19.935 & 20.506 \\
\hline & & $(3.480)$ & $(3.927)$ \\
\hline \multicolumn{2}{|l|}{ Dummy for woman consumes } & 0.284 & 0.325 \\
\hline \multicolumn{2}{|l|}{ fruits daily or weekly } & $(0.451)$ & $(0.468)$ \\
\hline \multicolumn{2}{|l|}{ Dummy for woman consumes } & 0.960 & 0.975 \\
\hline \multicolumn{2}{|l|}{ green vegetables daily or weekly } & $(0.197)$ & $(0.156)$ \\
\hline \multirow[t]{2}{*}{ Dummy for woman smokes } & & 0.020 & 0.028 \\
\hline & & $(0.141)$ & $(0.164)$ \\
\hline \multirow{2}{*}{$\begin{array}{l}\text { Number of living children } \\
\text { woman has }\end{array}$} & 3.403 & 3.582 & 3.604 \\
\hline & $(1.748)$ & $(1.778)$ & $(1.771)$ \\
\hline \multicolumn{4}{|l|}{ Husband-specific } \\
\hline \multirow[t]{2}{*}{ Husband's age } & 35.324 & 37.678 & 39.543 \\
\hline & $(7.759)$ & $(9.015)$ & $(9.091)$ \\
\hline \multirow{2}{*}{$\begin{array}{l}\text { Dummy for husband has } \\
\text { no education }\end{array}$} & 0.379 & 0.329 & 0.336 \\
\hline & $(0.485)$ & $(0.470)$ & $(0.472)$ \\
\hline \multirow{2}{*}{$\begin{array}{l}\text { Dummy for husband has } \\
\text { some or all primary school }\end{array}$} & 0.267 & 0.211 & 0.175 \\
\hline & $(0.442)$ & $(0.408)$ & $(0.380)$ \\
\hline \multirow{2}{*}{$\begin{array}{l}\text { Dummy for husband has } \\
\text { some secondary school }\end{array}$} & 0.243 & 0.213 & 0.386 \\
\hline & $(0.429)$ & $(0.409)$ & $(0.487)$ \\
\hline \multirow{2}{*}{$\begin{array}{l}\text { Dummy for husband has comp. } \\
\text { secondary school or higher }\end{array}$} & 0.110 & 0.247 & 0.095 \\
\hline & $(0.313)$ & $(0.431)$ & $(0.293)$ \\
\hline
\end{tabular}


Table 2: Means and standard deviations of exogenous characteristics by year continued.

\begin{tabular}{|c|c|c|c|}
\hline Variables & 1992 & 1998 & 2005 \\
\hline \multicolumn{4}{|l|}{ Husband-specific continued } \\
\hline Dummy for husband works in & 0.438 & 0.539 & 0.498 \\
\hline farming, fishing, hunt., or logging & $(0.496)$ & $(0.498)$ & $(0.500)$ \\
\hline \multicolumn{4}{|l|}{ Household-specific } \\
\hline \multirow[t]{2}{*}{ Rural household } & 0.758 & 0.766 & 0.724 \\
\hline & $(0.428)$ & $(0.424)$ & $(0.447)$ \\
\hline \multirow[t]{2}{*}{ Age of household head } & 43.155 & 43.590 & 43.555 \\
\hline & (13.830) & (13.020) & (11.965) \\
\hline Dummy for household has a & 0.943 & 0.929 & 0.877 \\
\hline male head & $(0.232)$ & $(0.256)$ & $(0.328)$ \\
\hline Dummy for household & 0.810 & 0.811 & 0.803 \\
\hline religion is Hinduism & $(0.393)$ & $(0.392)$ & $(0.398)$ \\
\hline Dummy for household belongs to & 0.219 & 0.289 & 0.294 \\
\hline Scheduled Caste/Scheduled Tribe & $(0.414)$ & $(0.453)$ & $(0.456)$ \\
\hline Dummy for household has & 0.486 & 0.559 & 0.615 \\
\hline electricity & $(0.500)$ & $(0.496)$ & $(0.487)$ \\
\hline Dummy for household & 0.440 & 0.505 & 0.569 \\
\hline owns a bicycle & $(0.496)$ & $(0.500)$ & $(0.495)$ \\
\hline Dummy for household & 0.046 & 0.072 & 0.115 \\
\hline owns a refrigerator & $(0.209)$ & $(0.259)$ & $(0.318)$ \\
\hline Dummy for household owns a & 0.367 & 0.342 & 0.292 \\
\hline radio or transistor & $(0.482)$ & $(0.474)$ & $(0.455)$ \\
\hline Dummy for household & 0.175 & 0.298 & 0.404 \\
\hline owns a television & $(0.380)$ & $(0.457)$ & $(0.491)$ \\
\hline Dummy for household & 0.074 & 0.098 & 0.155 \\
\hline owns a motorcycle & $(0.261)$ & $(0.297)$ & $(0.362)$ \\
\hline Source of drinking water: piped & 0.304 & 0.332 & 0.349 \\
\hline water & $(0.460)$ & $(0.471)$ & $(0.477)$ \\
\hline Source of drinking water: ground & 0.277 & 0.435 & 0.500 \\
\hline water & $(0.448)$ & $(0.496)$ & $(0.500)$ \\
\hline Source of drinking water: well & 0.367 & 0.203 & 0.122 \\
\hline water & $(0.482)$ & $(0.403)$ & $(0.327)$ \\
\hline Source of drinking water: surface & 0.036 & 0.023 & 0.019 \\
\hline water & $(0.187)$ & $(0.151)$ & $(0.135)$ \\
\hline Source of drinking water: rain- & 0.017 & 0.006 & 0.010 \\
\hline water, tanker truck, other & $(0.128)$ & $(0.078)$ & $(0.100)$ \\
\hline
\end{tabular}


Table 2: Means and standard deviations of exogenous characteristics by year continued.

\begin{tabular}{|lccc|}
\hline Variable & 1992 & 1998 & 2005 \\
\hline State-specific & & & \\
Per capita net state domestic & 1795.105 & 1998.875 & 2328.876 \\
product (base 1980-1981) & $(588.570)$ & $(829.643)$ & $(1138.096)$ \\
Average rainfall in millimeters & 269.129 & 278.445 & $(148.093)$ \\
& $(118.598)$ & $(133.415)$ & 26.185 \\
Average water temperature in & 26.824 & 26.385 & $(3.932)$ \\
degrees Celsius & $(3.628)$ & $(3.824)$ & 10.974 \\
Log number of malaria cases & & 9.576 & $(1.452)$ \\
& & $(0.000)$ & 0.205 \\
Dummy for rice producing state & 0.186 & 0.208 & $(0.404)$ \\
& $(0.389)$ & $(0.406)$ & 0.308 \\
Dummy for wheat producing & 0.339 & 0.308 & $(0.462)$ \\
state & $(0.473)$ & $(0.462)$ & 0.318 \\
Dummy for application months & 0.315 & 0.317 & $(0.466)$ \\
for rice crop & $(0.465)$ & $(0.465)$ & 0.535 \\
Dummy for application months & 0.532 & 0.537 & $(0.499)$ \\
for wheat crop & $(0.499)$ & $(0.499)$ & 0.377 \\
Dummy for northern states & 0.349 & 0.349 & $(0.485)$ \\
& $(0.477)$ & $(0.477)$ & 0.121 \\
Dummy for eastern states & 0.087 & 0.102 & $(0.326)$ \\
& $(0.282)$ & $(0.302)$ & 0.206 \\
Dummy for southern states & 0.234 & 0.230 & $(0.404)$ \\
Dummy for western states & $(0.423)$ & $(0.421)$ & 0.296 \\
& 0.329 & 0.320 & $(0.456)$ \\
\hline
\end{tabular}

Notes: Authors' calculations. Weighted to national levels by weights provided by the DHS. Standard deviations in parentheses. Number of observations in 1992 is 83, 899, number of observations in 1998 is 130, 222, and number of observations in 2005 is $158,393$. 
Table 3: Means and standard deviations of outcomes by year.

\begin{tabular}{|lccc|}
\hline Outcomes & 1992 & 1998 & 2005 \\
\hline $\begin{array}{l}\text { Infant was born alive but died at or less } \\
\text { than eleven months (infant mortality) }\end{array}$ & 0.086 & 0.078 & 0.075 \\
& $(0.280)$ & $(0.269)$ & $(0.263)$ \\
$\begin{array}{l}\text { Infant was born alive but died } \\
\text { in the first month (neo-natal mortality) }\end{array}$ & 0.054 & 0.051 & 0.050 \\
& $(0.226)$ & $(0.221)$ & $(0.218)$ \\
$\begin{array}{l}\text { Infant was born alive but died between the } \\
\text { first and eleventh month (post-natal }\end{array}$ & 0.032 & 0.027 & 0.025 \\
mortality) & $(0.176)$ & $(0.162)$ & $(0.155)$ \\
Gender of child is male & 0.513 & 0.519 & 0.518 \\
& $(0.500)$ & $(0.500)$ & $(0.500)$ \\
Birth weight (in kilograms) & 2.799 & 2.787 & 2.808 \\
& $(0.799)$ & $(0.704)$ & $(0.693)$ \\
Height-for-age z score for child & -2.118 & -1.857 & -1.727 \\
(less than 5 years old) & $(1.705)$ & $(1.654)$ & $(1.586)$ \\
$\begin{array}{l}\text { Weight-for-age z score for child } \\
\text { (less than 5 years old) }\end{array}$ & -2.094 & -1.875 & -1.875 \\
& $(1.269)$ & $(1.320)$ & $(1.165)$ \\
\hline
\end{tabular}

Notes: Authors' calculations. Weighted to national levels by weights provided by the DHS. Standard deviations in parentheses. Number of observations in 1992 is 83, 899, number of observations in 1998 is 130, 222, and number of observations in 2005 is 158,393 . Birth weight, height-for-age z score, and weight-for-age z score have fewer observations in each year. 
Table 4: Pairwise correlation coefficients of outcomes and presence of fertilizer agrichemicals in the month of conception.

\begin{tabular}{|c|c|c|c|c|c|c|c|}
\hline & \multicolumn{7}{|c|}{ Outcomes } \\
\hline & $\begin{array}{c}\text { Infant } \\
\text { mortality }\end{array}$ & $\begin{array}{l}\text { Neo-natal } \\
\text { mortality }\end{array}$ & $\begin{array}{l}\text { Post-natal } \\
\text { mortality }\end{array}$ & $\begin{array}{l}\text { Gender of child } \\
\text { is male }\end{array}$ & $\begin{array}{l}\text { Low birth weight } \\
(<2.5 \mathrm{kgs} \text {. at birth })\end{array}$ & $\begin{array}{l}\text { Height-for-age z score } \\
\text { (less than } 5 \text { years old) }\end{array}$ & $\begin{array}{l}\text { Weight-for-age } \mathrm{z} \text { score } \\
\text { (less than } 5 \text { years old) }\end{array}$ \\
\hline $\begin{array}{l}\text { Fertilizer in } \\
\text { first month }\end{array}$ & $0.108^{* *}$ & $0.088^{* *}$ & $0.087^{* *}$ & $-0.004^{* *}$ & $0.013^{* *}$ & $-0.040^{* *}$ & $-0.030^{* *}$ \\
\hline
\end{tabular}

Notes: Authors' calculations. The notation ${ }^{* * *}$ is $\mathrm{p}<0.01,{ }^{* *}$ is $\mathrm{p}<0.05,{ }^{*}$ is $\mathrm{p}<0.10$.

Table 5: Pairwise correlation coefficients of long-run outcomes and birth weight.

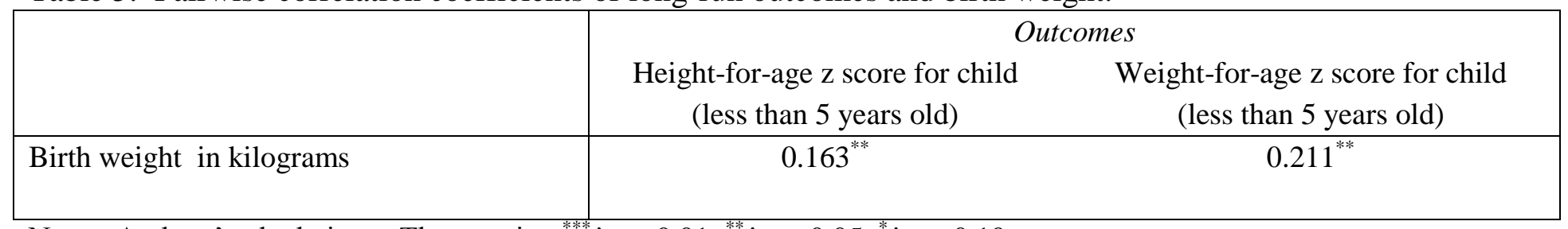

Notes: Authors' calculations. The notation ${ }^{* * *}$ is $\mathrm{p}<0.01,{ }^{* *}$ is $\mathrm{p}<0.05,{ }^{*}$ is $\mathrm{p}<0.10$.

Table 6: Pairwise correlation coefficients of outcomes and trimester averages of fertilizer agrichemicals presence in water.

\begin{tabular}{|c|c|c|c|c|c|c|c|}
\hline & $\begin{array}{c}\text { Infant } \\
\text { mortality }\end{array}$ & $\begin{array}{l}\text { Neo-natal } \\
\text { mortality }\end{array}$ & $\begin{array}{l}\text { Post-natal } \\
\text { mortality }\end{array}$ & $\begin{array}{c}\text { Gender of } \\
\text { child is male }\end{array}$ & $\begin{array}{l}\text { Low birth-weight } \\
\text { baby }(<2.5 \mathrm{kgs} \text {. })\end{array}$ & $\begin{array}{l}\text { Height-for-age } \\
\text { z score }\end{array}$ & $\begin{array}{l}\text { Weight-for age } \\
\text { z score }\end{array}$ \\
\hline $\begin{array}{l}\text { Trimester I average of fertilizer } \\
\text { agrichemicals in water }\end{array}$ & $0.118^{* *}$ & $0.101^{* *}$ & $0.090^{* *}$ & $-0.004^{* *}$ & $0.015^{* *}$ & $-0.039^{* *}$ & $-0.028^{* *}$ \\
\hline $\begin{array}{l}\text { Trimester II average of fertilizer } \\
\text { agrichemicals in water }\end{array}$ & $0.117^{* *}$ & $0.102^{* *}$ & $0.086^{* *}$ & $-0.003^{* *}$ & $0.015^{* *}$ & $-0.025^{* *}$ & $-0.016^{* *}$ \\
\hline $\begin{array}{l}\text { Trimester III average of fertilizer } \\
\text { agrichemicals in water }\end{array}$ & $0.114^{* *}$ & $0.099^{* *}$ & $0.083^{* *}$ & -0.003 & $0.018^{* *}$ & $-0.022^{* *}$ & $-0.010^{* *}$ \\
\hline
\end{tabular}


Table 7: First-stage regressions of fertilizer agrichemicals on identifying instruments.

\begin{tabular}{|c|c|c|c|}
\hline $\begin{array}{l}\text { Identifying } \\
\text { Instruments }\end{array}$ & \multicolumn{3}{|c|}{$\begin{array}{c}\text { Endogenous variable: Average of the dummy for presence of fertilizer } \\
\text { agrichemicals in month of conception }\end{array}$} \\
\hline Rice state $\mathrm{x}$ Rice sown & $\begin{array}{l}-0.007 \\
(0.006)\end{array}$ & $\begin{array}{l}-0.094^{* *} \\
(0.037)\end{array}$ & $\begin{array}{l}-0.108^{* * *} \\
(0.034)\end{array}$ \\
\hline Wheat state $\mathrm{x}$ Wheat sown & $\begin{array}{l}0.013^{* * *} \\
(0.003)\end{array}$ & $\begin{array}{l}0.118^{* * *} \\
(0.017)\end{array}$ & $\begin{array}{l}0.116^{* * * *} \\
(0.012)\end{array}$ \\
\hline $\begin{array}{l}\text { Includes indicators for crop states and months of } \\
\text { application }\end{array}$ & YES & YES & YES \\
\hline Includes child-specific characteristics & NO & YES & YES \\
\hline $\begin{array}{l}\text { Includes woman-specific characteristics, husband } \\
\text {-specific characteristics, and state-specific chars. }\end{array}$ & NO & YES & YES \\
\hline $\begin{array}{l}\text { Includes month and year of conception } \\
\text { dummies, region dummies, and interactions } \\
\text { of year of conception and region dummies }\end{array}$ & NO & NO & YES \\
\hline R-squared & 0.003 & 0.073 & 0.199 \\
\hline F-statistic & 11.560 & 25.770 & 48.700 \\
\hline & {$[0.000]$} & {$[0.000]$} & {$[0.000]$} \\
\hline Observations & 372514 & 11676 & 11676 \\
\hline
\end{tabular}

Notes: Weighted to national level with weights provided by the DHS. Table reports OLS regressions. Standard errors in parentheses are clustered by state. $p$-values in square brackets. The notation ${ }^{* * *}$ is $p<0.01,{ }^{* *}$ is $p<0.05,{ }^{*}$ is $p<0.10$. The "rice state" dummy equals one for Andhra Pradesh, Tamil Nadu, West Bengal and Assam, and zero otherwise. The "rice sown" dummy equals one for the months of June through September, and zero otherwise. The "wheat state" dummy equals one for Punjab, Haryana, Uttar Pradesh, and Gujarat, and zero otherwise. The "wheat sown" dummy equals one for the months of November through April, and zero otherwise. F-statistics reported are for the identifying instruments. Regressions include a constant term and other characteristics as noted in the table. 
Table 8: Instrumental variables effects of fertilizer agrichemicals on outcomes that are most impacted in the first trimester.

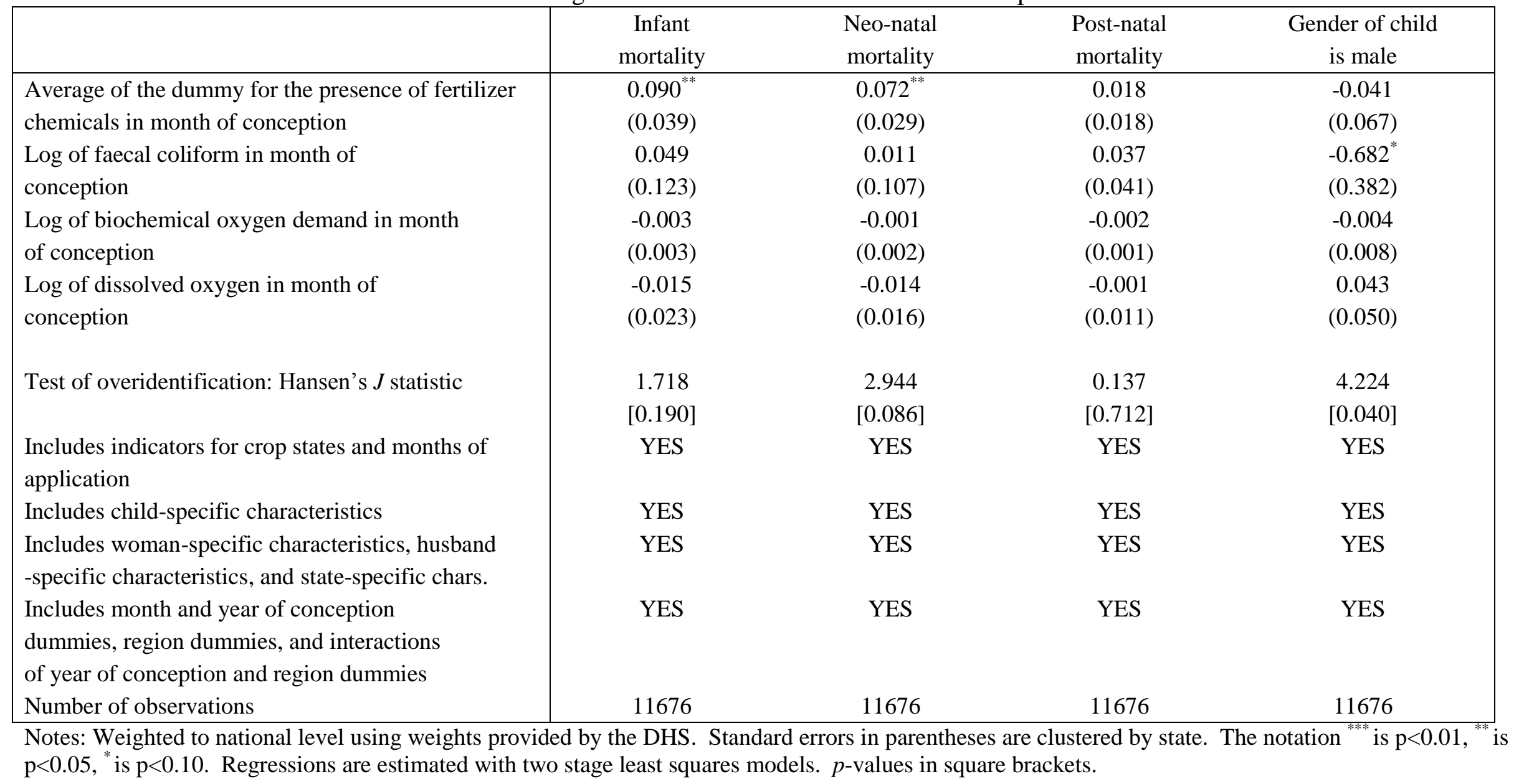


Table 9: Instrumental variables effects of fertilizer agrichemicals on outcomes that are most impacted in the third trimester and long-run outcomes.

\begin{tabular}{|c|c|c|c|}
\hline & $\begin{array}{l}\text { Birth weight } \\
\text { in kilograms }\end{array}$ & $\begin{array}{l}\text { Height-for-age } \\
\text { z score }\end{array}$ & $\begin{array}{l}\text { Weight-for-age } \\
\text { z score }\end{array}$ \\
\hline Average of the dummy for the presence of fertilizer & -0.951 & $-1.431^{* *}$ & $-2.102^{* *}$ \\
\hline chemicals in month of conception & $(0.689)$ & $(0.636)$ & $(1.026)$ \\
\hline Log of faecal coliform in month of & -4.343 & $-35.033^{* *}$ & $-34.392^{*}$ \\
\hline conception & $(3.873)$ & $(17.125)$ & $(20.596)$ \\
\hline Log of biochemical oxygen demand in & 0.021 & -0.510 & -2.083 \\
\hline month of conception & $(0.045)$ & $(2.301)$ & $(1.869)$ \\
\hline Log of dissolved oxygen in month of & $1.138^{*}$ & 0.019 & -0.227 \\
\hline conception & $(0.696)$ & $(1.040)$ & $(1.190)$ \\
\hline \multirow[t]{2}{*}{ Test of overidentification: Hansen's $J$ statistic } & 1.052 & 0.004 & 0.057 \\
\hline & [0.305] & [0.950] & [0.811] \\
\hline $\begin{array}{l}\text { Includes indicators for crop states and months of } \\
\text { application }\end{array}$ & YES & YES & YES \\
\hline Includes child-specific characteristics & YES & YES & YES \\
\hline $\begin{array}{l}\text { Includes woman-specific characteristics, husband } \\
\text {-specific characteristics, and state-specific chars. }\end{array}$ & YES & YES & YES \\
\hline $\begin{array}{l}\text { Includes month and year of conception } \\
\text { dummies, region dummies, and interactions } \\
\text { of year of conception and region dummies }\end{array}$ & YES & YES & YES \\
\hline Number of observations & 1514 & 5248 & 5248 \\
\hline
\end{tabular}

$\mathrm{p}<0.05,{ }^{*}$ is $\mathrm{p}<0.10$. Regressions are estimated with two stage least squares models. $p$-values in square brackets 
Table 10: Disaggregated instrumental variables effects of the presence of fertilizer agrichemicals in month of conception.

\begin{tabular}{|c|c|c|c|c|c|c|}
\hline & \multicolumn{6}{|c|}{ Neo-natal mortality } \\
\hline & $\begin{array}{l}\text { Uneducated } \\
\text { women }\end{array}$ & $\begin{array}{c}\text { Educated } \\
\text { women }\end{array}$ & $\begin{array}{l}\text { Rural } \\
\text { areas }\end{array}$ & $\begin{array}{l}\text { Urban } \\
\text { areas }\end{array}$ & $\begin{array}{c}\text { Poor } \\
\text { households }\end{array}$ & $\begin{array}{c}\text { Rich } \\
\text { households }\end{array}$ \\
\hline Average of the dummy for the presence of & $0.089^{* *}$ & $0.040^{* *}$ & $0.069^{* *}$ & 0.099 & $0.062^{* *}$ & 0.025 \\
\hline fertilizer chemicals in month of conception & $(0.036)$ & $(0.020)$ & $(0.031)$ & $(0.066)$ & $(0.029)$ & $(0.037)$ \\
\hline Log of faecal coliform in month of & 0.255 & -0.055 & 0.132 & -0.044 & 0.044 & 0.014 \\
\hline conception & $(0.348)$ & $(0.090)$ & $(0.448)$ & $(0.055)$ & $(0.313)$ & $(0.044)$ \\
\hline Log of biochemical oxygen demand in month & -0.002 & 0.001 & -0.001 & -0.004 & -0.001 & 0.004 \\
\hline of conception & $(0.003)$ & $(0.002)$ & $(0.003)$ & $(0.003)$ & $(0.002)$ & $(0.003)$ \\
\hline Log of dissolved oxygen in month of & -0.021 & -0.006 & -0.014 & -0.011 & -0.012 & $-0.050^{* *}$ \\
\hline conception & $(0.017)$ & $(0.017)$ & $(0.016)$ & $(0.022)$ & $(0.014)$ & $(0.022)$ \\
\hline $\begin{array}{l}\text { Includes indicators for crop states and months of } \\
\text { application }\end{array}$ & YES & YES & YES & YES & YES & YES \\
\hline Includes child-specific characteristics & YES & YES & YES & YES & YES & YES \\
\hline Includes woman-specific characteristics, husband & YES & YES & YES & YES & YES & YES \\
\hline $\begin{array}{l}\text {-specific characteristics, and state-specific chars. } \\
\text { Includes month and year of conception } \\
\text { dummies, region dummies, and interactions } \\
\text { of year of conception and region dummies }\end{array}$ & YES & YES & YES & YES & YES & YES \\
\hline Number of observations & 7038 & 4638 & 8995 & 2681 & 7598 & 532 \\
\hline
\end{tabular}

Notes: Weighted to national level using weights provided by the DHS. Standard errors in parentheses are clustered by state. The notation ${ }^{* * *}$ is $p<0.01,{ }^{* *}$ is
$\mathrm{p}<0.05,{ }^{*}$ is $\mathrm{p}<0.10$. Regressions are estimated with two stage least squares models. Uneducated women have no schooling; educated women either have some or all primary school, some secondary school, or have completed secondary school or higher. Uneducated women form 58 percent of the sample. Rich households are those who own a refrigerator, television, and motorcycle; the poor households are those who own none of these assets. 
Table 11: Instrumental variables effects: impact of first trimester average of the presence of fertilizer agrichemicals in water.

\begin{tabular}{|c|c|c|c|}
\hline & $\begin{array}{c}\text { Infant } \\
\text { mortality }\end{array}$ & $\begin{array}{l}\text { Neo-natal } \\
\text { mortality }\end{array}$ & $\begin{array}{l}\text { Post-natal } \\
\text { mortality }\end{array}$ \\
\hline Average of the dummy for the presence of & $0.102^{* * *}$ & $0.080^{* * *}$ & 0.022 \\
\hline fertilizer in the first trimester months & $(0.036)$ & $(0.026)$ & $(0.019)$ \\
\hline Log of the first trimester average of faecal & 0.006 & 0.001 & $0.005^{*}$ \\
\hline coliform & $(0.004)$ & $(0.002)$ & $(0.003)$ \\
\hline Log of the first trimester average of & 0.001 & 0.002 & -0.002 \\
\hline biochemical oxygen demand & $(0.004)$ & $(0.004)$ & $(0.001)$ \\
\hline Log of the first trimester average of dissolved & 0.002 & 0.003 & -0.001 \\
\hline oxygen & $(0.013)$ & $(0.009)$ & $(0.005)$ \\
\hline $\begin{array}{l}\text { Includes indicators for crop states and months of } \\
\text { application }\end{array}$ & YES & YES & YES \\
\hline Includes child-specific characteristics & YES & YES & YES \\
\hline Includes woman-specific characteristics, husband & YES & YES & YES \\
\hline $\begin{array}{l}\text {-specific characteristics, and state-specific chars. } \\
\text { Includes month and year of conception } \\
\text { dummies, region dummies, and interactions } \\
\text { of year of conception and region dummies }\end{array}$ & YES & YES & YES \\
\hline Number of observations & 11634 & 11634 & 11634 \\
\hline
\end{tabular}


Table 12: Robustness checks with respect to average rainfall, water temperature, and malaria cases

\begin{tabular}{|c|c|c|c|c|c|c|c|c|c|}
\hline & $\begin{array}{c}\text { Infant } \\
\text { mortality }\end{array}$ & $\begin{array}{l}\text { Infant } \\
\text { mortality }\end{array}$ & $\begin{array}{l}\text { Infant } \\
\text { mortality }\end{array}$ & $\begin{array}{l}\text { Neo-natal } \\
\text { mortality }\end{array}$ & $\begin{array}{l}\text { Neo-natal } \\
\text { mortality }\end{array}$ & $\begin{array}{l}\text { Neo-natal } \\
\text { mortality }\end{array}$ & $\begin{array}{l}\text { Post-natal } \\
\text { mortality }\end{array}$ & $\begin{array}{l}\text { Post-natal } \\
\text { mortality }\end{array}$ & $\begin{array}{l}\text { Post-natal } \\
\text { mortality }\end{array}$ \\
\hline Average of the dummy for presence & $0.091^{* *}$ & $0.092^{*}$ & $0.183^{* *}$ & $0.062^{*}$ & $0.076^{*}$ & $0.117^{*}$ & 0.022 & 0.018 & $0.067^{*}$ \\
\hline of fert. chem. in month of conception & $(0.042)$ & $(0.047)$ & $(0.080)$ & $(0.033)$ & $(0.041)$ & $(0.062)$ & $(0.021)$ & $(0.018)$ & $(0.037)$ \\
\hline \multirow[t]{2}{*}{ Average rainfall } & -0.00001 & & & -0.00001 & & & 0.00000001 & & \\
\hline & $(0.00001)$ & & & $(0.00001)$ & & & $(0.000004)$ & & \\
\hline Water temperature & & -0.001 & & & -0.0003 & & & -0.0001 & \\
\hline & & $(0.001)$ & & & $(0.0005)$ & & & $(0.0002)$ & \\
\hline \multirow[t]{2}{*}{ Log number of malaria cases } & & & 0.0001 & & & -0.0003 & & & 0.001 \\
\hline & & & $(0.002)$ & & & $(0.001)$ & & & $(0.001)$ \\
\hline Test of overidentification: Hansen's & 1.566 & 1.895 & 0.535 & 2.639 & 3.056 & 4.011 & 0.155 & 0.106 & 1.427 \\
\hline$J$ statistic & [0.211] & [0.169] & {$[0.465]$} & [0.104] & {$[0.081]$} & {$[0.045]$} & [0.694] & {$[0.745]$} & {$[0.232]$} \\
\hline Includes measures of water pollutants & YES & YES & YES & YES & YES & YES & YES & YES & YES \\
\hline $\begin{array}{l}\text { Includes indicators for crop states and } \\
\text { months of application }\end{array}$ & YES & YES & YES & YES & YES & YES & YES & YES & YES \\
\hline Includes child-specific characteristics & YES & YES & YES & YES & YES & YES & YES & YES & YES \\
\hline Includes woman-specific, husband & YES & YES & YES & YES & YES & YES & YES & YES & YES \\
\hline -specific, and state-specific chars. & & & & & & & & & \\
\hline $\begin{array}{l}\text { Includes month and year of conception } \\
\text { dum region dummies, and interactions }\end{array}$ & YES & YES & YES & YES & YES & YES & YES & YES & YES \\
\hline of year of conception and region dum. & & & & & & & & & \\
\hline Number of observations & 10613 & 11140 & 6819 & 13437 & 14004 & 6233 & 10613 & 11140 & 6819 \\
\hline
\end{tabular}

Notes: Weighted to national level using weights provided by the DHS. Standard errors in parentheses are clustered by state. The notation ${ }^{* * * *}$ is $p<0.01{ }^{* * *}$ is $\mathrm{p}<0.05,{ }^{*}$ is $\mathrm{p}<0.10$. Regressions are estimated with two stage least squares models. $p$-values in square brackets. Average rainfall is measured by state and year of conception. Water temperature is measured by state, year of conception and month of conception. Number of malaria cases is measured by state and year of conception. Information on malaria is available only for 1999-2002 and 2005. 
Appendix Table 1: OLS effects of fertilizer agrichemicals in water on outcomes that are most impacted in the first trimester

\begin{tabular}{|c|c|c|c|c|}
\hline & $\begin{array}{c}\text { Infant } \\
\text { mortality }\end{array}$ & $\begin{array}{l}\text { Neo-natal } \\
\text { mortality }\end{array}$ & $\begin{array}{l}\text { Post-natal } \\
\text { mortality }\end{array}$ & $\begin{array}{c}\text { Gender of child } \\
\text { is male }\end{array}$ \\
\hline Average of the dummy for the presence of fertilizer & -0.002 & -0.002 & -0.00003 & -0.011 \\
\hline chemicals in month of conception & $(0.002)$ & $(0.003)$ & $(0.002)$ & $(0.008)$ \\
\hline \multirow[t]{2}{*}{ Log of faecal coliform in month of conception } & -0.082 & -0.088 & 0.006 & $-0.648^{*}$ \\
\hline & $(0.200)$ & $(0.179)$ & $(0.037)$ & $(0.343)$ \\
\hline \multirow{2}{*}{$\begin{array}{l}\text { Log of biochemical oxygen demand in month of } \\
\text { conception }\end{array}$} & -0.003 & -0.001 & $-0.002^{* *}$ & -0.005 \\
\hline & $(0.002)$ & $(0.002)$ & $(0.001)$ & $(0.009)$ \\
\hline \multirow[t]{2}{*}{ Log of dissolved oxygen in month of conception } & -0.009 & -0.010 & 0.001 & 0.042 \\
\hline & $(0.022)$ & $(0.015)$ & $(0.010)$ & $(0.044)$ \\
\hline $\begin{array}{l}\text { Includes indicators for crop states and months of } \\
\text { application }\end{array}$ & YES & YES & YES & YES \\
\hline Includes child-specific characteristics & YES & YES & YES & YES \\
\hline Includes woman-specific characteristics, husband & YES & YES & YES & YES \\
\hline $\begin{array}{l}\text {-specific characteristics, and state-specific chars. } \\
\text { Includes month and year of conception } \\
\text { dummies, region dummies, and interactions } \\
\text { of year of conception and region dummies }\end{array}$ & YES & YES & YES & YES \\
\hline Number of observations & 11676 & 11676 & 11676 & 11676 \\
\hline
\end{tabular}


Appendix Table 2: OLS effects of fertilizer agrichemicals in water on outcomes that are most impacted in the third trimester and long-run outcomes

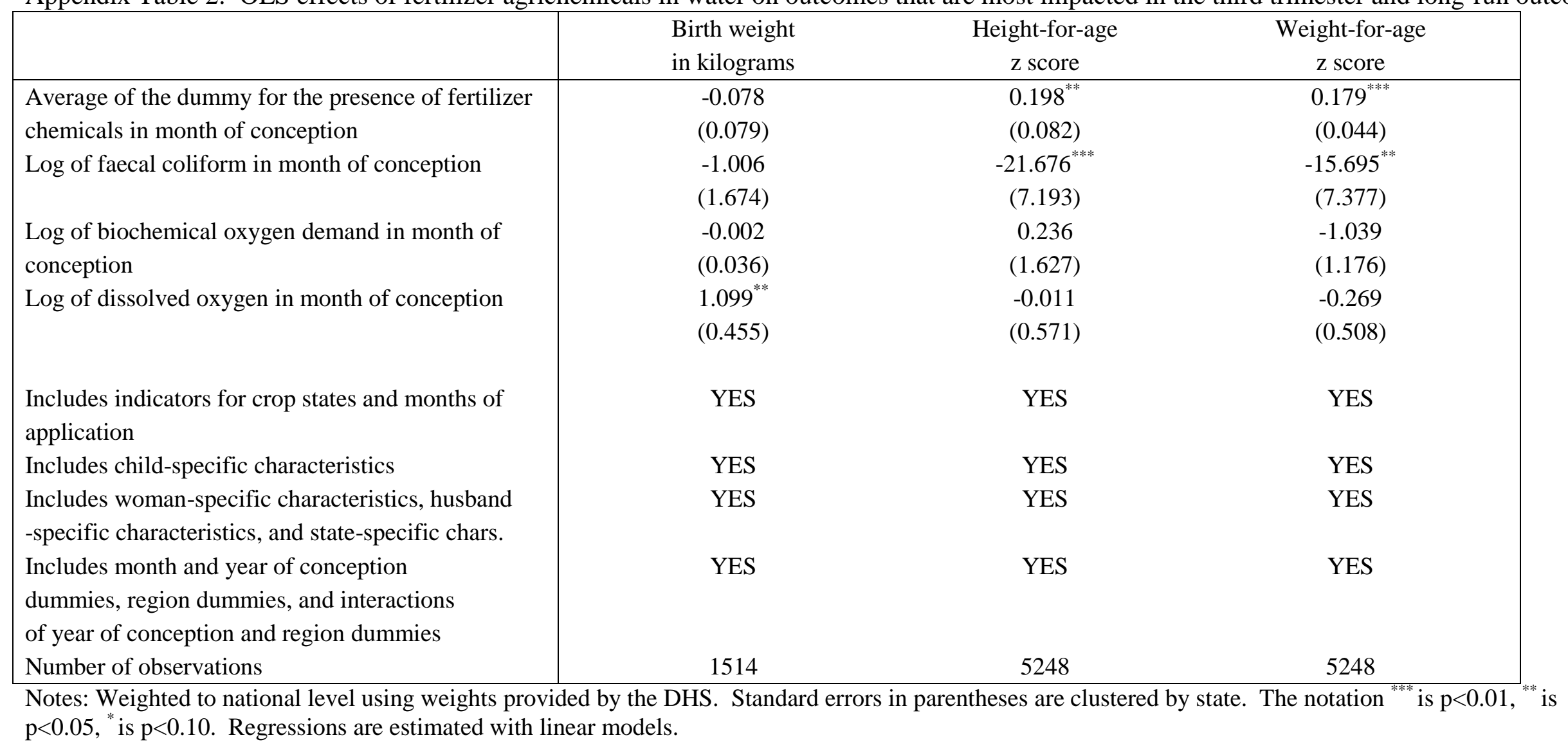

